\title{
Kırım ve Osmanl1-Rus Savaşları Arası Dönemde Canlanan Kültürel Hayat (1853-1878 )
}

\author{
The Flourishing Cultural Life in the Period between the Crimean War and \\ the Ottoman-Russian War (1853-1878)
}

\author{
Ahmet ÖZCAN ${ }^{1}$ D \\ Araştırma Makalesi \\ 1 Prof. Dr. - Çankırı Karatekin \\ Üniversitesi Edebiyat Fakültesi \\ ID ORCID: 0000-0002-6264-5977
}

\section{Sorumlu yazar/Corresponding} author:

Ahmet ÖZCAN

E-posta/E-mail:

kitapcigezgin@yahoo.com

Geliş tarihi/Received:

17 Ocak 2021

\section{Revizyon talebi/Revision}

Requested:

20 Şubat 2021

\section{Son revizyon /Last revision:}

04 Mart 2021

\section{Kabul tarihi/Accepted:}

26 Nisan 2021

\section{Atıf/Citation:}

Özcan, Ahmet. "Kırım ve Osmanl1Rus Savaşları Arası Dönemde Canlanan Kültürel Hayat (18531878)". Türk Savas Callsmalar Dergisi 2, no. 1 (2021): 76-98.

\section{Özet}

Türkiye'nin yakınçağ tarihinin yazımı genellikle modernleșme paradigmasından etkilenmiş, reformlara odaklı inkılap tarihçiliğinin etkisi altında kalmıştır. Siyasal aktör ve onların faaliyetlerini önceleyen bu tarih yazımı özellikle kültür tarihi çerçevesinde ele alınabilecek birçok olguyu ve bu olguların ortaya çıktğı süreci dikkate almamış veya aktörleri merkeze alarak açıklamaya çalışmıştır. Dolayısıyla savaşlar ve onların siyasal, toplumsal, kültürel sonuçları da bu merkeze bağlı olarak açıklanmaya çalışılmıştır. Esasında birçok anlamda büyük bir değişim ve fark edilir derecede ilklerin görüldüğ̈ 1860-1880 arası dönem Tanzimat ve Islahat gibi daha çok siyasal dönüşümü çağrnştıran kavramların gölgesinde kalmıştır. Bu kavramlar da kurumsal ve toplumsal değişimin önünü açan reformların yukarıdan aşağyya doğru uygulanmasına işaret etmektedir. Oysa bu çalışmada verilen örneklerden anlaşılacağı üzere resmi alanın dışında kalan ve resmi alanlarda bir ihtiyaç olarak doğan değişimlerin yanı sıra sivil alanların aşağıdan yukarıya doğru değişimi zorlayan etkisi büyüktür. Uluslararası bir ittifakla girişilen ilk harbin merakları cezbeden sürecinin sivil basın ve yayıncllĭg zorunlu bir ihtiyaca dönüştüren sonucu olmuştur. Harbin yıkıcı etkilerinin yanı sıra siyasal, toplumsal ve kültürel dinamizm kazandıran ve değişimi zorlayan sonuçları da görünmektedir. Kırım ve Osmanlı-Rus Harbi arasında kalan zaman dilimi bu anlamda dikkate değer birçok örnek içermektedir. Bu dönem birçok anlamda ilklerin yaşandığı bir atmosfer olmuştur.

Anahtar Kelimeler: Kırım Savaşı, Osmanlı-Rus Savaşı, Kültürel Hayat, Edebiyat

\section{Abstract}

The literature of Turkey's modern history has generally been influenced by the modernization paradigm, under the influence of reform-oriented historiography of the Turkish Revolution. This historiography, which prioritizes political actors and their activities, did not take into account many phenomena that can be dealt with especially within the framework of cultural history and the process in which these phenomena emerged or tried to explain the actors in the centre. Therefore, wars and their political, social and cultural consequences have been tried to be explained in relation to this centre. In fact, the period between 1860-1880, when a great change and noticeable firsts were seen in many ways, was mostly overshadowed by concepts such as Tanzimat and Islahat that evoke more political transformation. These concepts also point to the top-down implementation of reforms paving the way for institutional and social change. However, as can be seen from the examples given in this study, besides the changes that are outside the official area and arising as a need in the official areas, the effect of civilian areas that forces change from the bottom to the top is great. The fascinating process of the first war, initiated with an international alliance, was the result of the process that turned the civil press and broadcasting into a compulsory need. In addition to the destructive effects of the war, the consequences that bring political, social and cultural dynamism and force change are also visible. The period between the Crimean and the Ottoman-Russian War contains many remarkable examples in this sense. This period had been an atmosphere of firsts in many ways.

Key Words: Crimean War, Ottoman-Russian War, Cultural Life, Literature 


\section{GİRIŞ̧}

Çeyrek asırlık bir zamanı kapsayan iki harp arası dönemde genel hatlarıyla kültürel canlılı̆ga odaklandığımız bu çalışmada kültürel hayat kavramını farklı tanımlamaların sınırlarından çıkararak yazılı metinlerden okunabilir bir dünyanın birbirine paralel gelişen kurumları, araçları, ürünleri ve aktörleri üzerinden ele aldığımızı belirtelim. Eğitim-Öğretimin kurumsal ve zihinsel organizasyonu, bilimsel ve mesleki cemiyetler, matbuat âlemi ve edip kimlikleri ağır basan şair, romancı, gazeteci, mütefekkir, siyasal muhalif v.s. gibi bütününü kendisinden toplayarak öne çıkmış aydınlar ve dönemin ürünü olan bazı kavramlar bu çerçevede değerlendirilmiş, öncelikle matbuat ve aydınlar ana başlıkları oluşturmuştur. Bu unsurlar mümkün olduğu kadar birbiriyle bağlantılı olarak değerlendirilmelidir. Matbuat âlemindeki canlılık ve aydın sınıfın doğuşu birbiriyle paralel ve döngüsel gelişimin sonucudur. Modern eğitim-öğretim, müzik, resim ve sanat dünyasının diğer unsurları çalışmanın sınırları dışındadır. Çalışmamızda mümkün olduğunca ayrıntıya girilmezken, çok bilinen ve benzeri eserlerde tekrar eden bilgi ve yorumlara asgari seviyede müracaat edilmiştir.

Her ne kadar referanslarımızı daha çok ikinci el kaynaklar oluştursa da ele aldığımız dönem yeni bir tasvir denemesi ile açıklanmaya çalışlacaktır. Ele alınan zaman dilimin birinci referansı Kırım Savaşı'dır. Dolayısıyla 1877-78 Osmanlı-Rus Savaşı sonrasına vurgu asgari düzeyde kalmıştır. Aşağıda Kırım Savaşı'nın Türkiye'deki anlamı ve tarih yazımındaki karşıllğı üzerine kısa bir değerlendirme sonrasında esas konuya geçilecektir. Savaşların devletler ve toplumlar için birçok anlamda yıkıcı etki yaratmasının yanı sıra siyasal, toplumsal ve kültürel gelişmelere dinamizm getiren pozitif sonuçları olduğu yazımızın sonunda daha iyi değerlendirilecektir. Bu dönem, adı bir ferman veya rejim değişimi ifadesiyle sunulamayacak kadar Türkiye tarihinde önemli bir dönüm noktası olmuştur. Genellikle sivil gelişmeler üzerinden yorumlanan bu dönem modern entelektüel subay profilinin doğuşunu hazırlayacak olan ilklerin yaşandığı bir zaman dilimi olmuştur. Elbette burada ele alınmayacak olan modern eğitim-öğretim organizasyonu ve zihinsel dönüşümünün askeri alandaki karşllığ sonraki dönemlerde meyvesini verecek şekilde etkili olmuştur, fakat çalışmanın sınırları başlangıçta belirtildiği gibi matbuat ve entelektüel hayatla belirlenmiştir. Bu atmosferin imkanlarından yararlanma konusunda örnek verilmese ve doğrudan ifade edilmese de askeri alana etkisini dişarda tutmak mümkün değildir.

\section{ANA HATLARIYLA İKİ HARP ARASI DÖNEMDE GÖRÜNEN İLKLER}

Ahmet Hamdi Tanpınar'ın XIX. Asır Türk Edebiyatı Taribi adlı eserine bakıldığında büyük bölümünün 1860-1885 yılları arasını kapsadığ1 görülecektir. ${ }^{1}$ Edebiyat tarihçilerine cazip gelen çeyrek asırlık bu dönem, Batı kaynaklı yeni edebî türlerin girişiyle birlikte edebî üretimin yoğunlaştığı, eğitim ve kültür kurumlarının zamanın ihtiyaçlarına göre yeniden yapılandığı, "münevver" adı verilecek olan yeni bir zümrenin doğduğu bir zamana işaret etmektedir. Yalnız Tanpınar değil bütün Türk Edebiyatı tarihçileri 19. yüzyıl söz konusu olduğunda bu döneme yoğunlaşacaklardır. Burası modern Osmanlı-Türk edebiyatı tarihinin temellerinin bulunduğu ilklerin inşa alanıdır. ${ }^{2}$ Aynı zamanda içinde kökleri, kopmaları, karşılaşmaları, okuma, yazma, öğretme, öğrenme arzusunu, haber tutkusunu ve o devirde ortaya çıkan İslamcıllk, Türkçülük,

\footnotetext{
${ }^{1}$ Ahmet Hamdi Tampınar, XIX. Asır Türk Edebiyat Taribi, 1. Baskı, (İstanbul: İstanbul Üniversitesi Edebiyat Fakültesi Yayınları, 1949); 19.Baskı, (İstanbul: Dergâh Yayınları, 2012).

${ }^{2}$ Bkz. İsmail Habip, Tanzimattan Beri I-II, (İstanbul: Remzi Kitapevi, 1940-42): Türk Edebiyatı Taribine Bir Bakış, Editör: M. Kayahan Özgül, (Ankara: Kurgan Yayınları, 2015).
} 
Osmanlıcılık gibi ideolojilerin aracı olarak muhayyel kardeşlerin duygularına haber, şiir, tiyatro, fikir ve roman yoluyla tercüman olan metinleri barındırır. Bu dönem edebiyat tarihçilerinin yanı sıra siyasi, eğitim, askeri, bilim, basın ve kültür tarihçileri için de edebiyatta olduğu gibi birçok ilkin görünmeye başladığı canlılığın belirginleştiği tarihsel zaman dilimidir. ${ }^{3}$ Ulûmu fünûna dönüştürme arzusunun zirvesine gelinmiş, fünûnu, keşif ve icat mesabesinde olmasa da tanıtma arzusundaki cemiyetler ortaya çıkmış, cemiyetçilikle birlikte ilmi ve mesleki cemiyet ${ }^{4}$ sınırlarını aşan "siyasal firka" doğmuştur. ${ }^{5}$ Artık cemiyet kavramı ve cemiyetin kendisi entelektüel zihnin müsademe alanındadır. Aydın, tabii vazifesi olarak içinden çıktığı cemiyeti dönüştürmenin peşine düşmüştür. Gizli ve açık mahfillerde yapılacak toplantıların aktörleri vasıtasıyla "medeniyet, maarif, meşrutiyet, hürriyet, vatan, şura" vs. gibi kelimelere yeni anlamlar yüklenerek kavramsallaştırılmış ve Batıdaki benzerlerine karşılık olarak icat edilmiş bu kavramlarla zihinsel yolculuğa çıkılmışır ${ }^{6}$. Canlılık arz eden bu manzarayı Kırım Savaşı sonrasında ilan edilen Islahat Fermanı vasıtasıyla Batı'yı aldatmak veya mecburiyet hali olarak yapılan bir 1slahat gösterisi olarak açıklamak yerine dünyanın büyük çoğunluğunu saran birbirine benzer gelişmelerin yeryüzünün bu coğrafyasındaki tezahürü olduğu kabul edilmelidir. ${ }^{7}$

19.yüzyıl, Batı'nın merkezinden bakıldığında "katı olan her şeyin buharlaştı̆̆ı"” bir dünya olarak görünmektedir. Bu buharlaşmada Avrupa, devrimler, dönüşümler ve çatışmalar ${ }^{9}$ ve bütün bunlara paralel kültürel patlamalarla ${ }^{10}$ dünyayı anlamaya çalısan büyük kavramları üretmişti. Kavramlar işlevseldi; bu yüzyılda dünyayı anlamak, anlamlandırmak ve kendi diliyle açıklamak dünya hâkimiyetinin şartlarından biri haline gelmişti. Emperyalizm kavramının dünya hâkimiyeti

3 “...Ancak, bugün Türkiye’de yazı dilini sadeleştirilmesinden köklü sivil hürriyetlere kadar, kökleri yeni Osmanlıların öncü çalışmalarında yer almayan tek bir modernleşme alanı olduğunu söylemek zordur. Paradoksal olarak, Türk devletinin temellerini İslam’ı yeniden enjekte etmeye yönelik bugün görülen her ciddi teşebbüs, geriye onların zamanına da bakmak zorundadır. Çünkü Yeni Osmanlılar aynı zamanda hem Türkçe okuyan halkın entelektüel donatımının Aydınlanmacı kısmının fikirlerini hazırlayan ilk insanlardı ve hem de bu fikirlerle İslâm arasında bir sentez meydana getirmeye çalışan ilk düşünürlerdi..." Şerif Mardin, Yeni Osmanl Düşüncesinin Doğuşu, (çev.) Mümtaz’er Türköne-Fahri Unan-İrfan Erdoğan, 10.Baskı, (İstanbul: İletişim Yayınları, 2012), s.10. Tanzimat ve Islahat devrinin birçok yönünün ele alındığ1 eserler için bkz. Engelhardt, Tanžimat ve Türkize, Mütercim: Ali Reşad, Yayına Hazırlayan: Akın Bedirhan, (İstanbul: Kaknüs Yayınları, 1999); İlber Ortaylı, İmparatorluğun En Uzun Yüzyılı, (İstanbul: Timaş Yayınları, 2013); Tanz̧imat I, Maarif Matbaası 1940; Tanzৃimat, Halil İnalc1k-Mehmet Seyitdanlıŏglu, 2. Bask1, (İstanbul: Türkiye İş Bankası Kültür Yayınları, 2011),

4 İlmi ve mesleki cemiyetler için bkz. Osmanl İlmi ve Mesleki Cemiyetleri, 1. Milli Türk Bilim Tarihi Sempozyumu, 3-5 Nisan 1987, (ed.) Ekmeleddin İhsanoğlu, (İstanbul: İstanbul Üniversitesi Edebiyat Fakültesi Basımevi, 1987).

${ }^{5}$ Bknz. Şerif Mardin, age

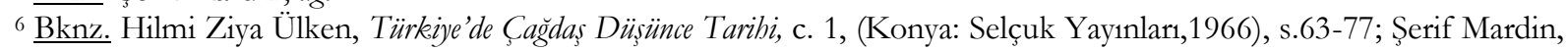
age.

7 “ Bütün bu açıklamalardan anlaşılıyor ki "Islahat Fermanı” yabancı devletlerin hazırladığı ve Bâb-1 Âli’nin kabul etmek zorunda kaldığı bir ıslahat programıdır.” Enver Ziya Karal, Osmanl Taribi, c.5, 6. Baskı, (Ankara: TTK Yayınları, Ankara 1994), s.250.

8 Bu deyim Berman'ın aynı adlı kitabından alınmıştır. Berman bu eserinde “ modernizmi, modern insanların modernleşmenin nesneleri oldukları kadar özneleri de olmak. Modern dünyada sıkıca tutunabilecekleri bir yer bulmak ve kendilerini bu dünyada evde hissetmek için giriştikleri çabalar olarak..."tanımlar. Bknz. Marshall Berman, Katı Olan Her Șey Buharlașıyor,18. Baskı, (çev.) Ümit Altuğ-Bülent Peker, (İstanbul: İletișim Yayınları, 2016).s. 11 .Berman bu ifadeyi Marx’ın “ modern olmak katı olan her şeyin buharlaşıp gittiği bir evrenin parçası olmaktır” şeklindeki yorumundan alır. s.27.

9 Avrupa'daki gelişmeleri E.J. Hosbawm bir dizi halinde yazmıștır. Bunların Dost Kitapevi tarafından yayınlanmış örnekleri için bknz. Sanayi ve Imparatorluk, 4. Bask1, (çev.) Abdullah Ersoy, (Ankara: Dost Kitabevi, 2008); Devrim Că̆g, (çev.) Bahadır Sina Şener, (Ankara: Dost Kitabevi, 2012); Sermaye Că̆ı, 5. Baskı, (çev.) Mustafa Sina Şener, (Ankara: Dost Kitabevi, 2012;) Ayrıca bknz. C.A. Bayly, Modern Dünyanın Doğuşu, (çev.)M. Neva Şellaki, (İstanbul: Ayrıntı Yayınları, 2014).

10 19. Yüzyıl Avrupası'nın kültür tarihi için bknz. Donald Sassoon, The Culture of The Europeans, From 1800 To The Present, (London: Harper Press, 2006). 
sürecinde olup bitenleri açıllayıcı bir yanı olsa da "Emperyalizmin Türkiye'ye girişi” başlığıyla ifade edilmek istenenler ancak iktisadi bir sürecin analizine yetebilirdi, fakat olup bitenleri bütünlük içinde görmeye yetmiyordu. ${ }^{11}$ İnk1lâp tarihçilerinin olgulanı, "büyük inkılaba" giden yoldaki taşlar olarak görme eğilimiyle belirginleşen tasarrufu da bize Kırım Savaşı'nın dünya tarihindeki yeriyle Osmanlı tarihi arasındaki yeri arasındaki farkı veya benzerlikleri açıklamaya yetmedi. Dickens'in romanlarına yansıyan Londra, İngiliz işçi sınıfının tarihinin neden yazılması gerektiğini gösterirken bu devirde Osmanlı amelesini işçi sınıfı çözümlemeleri içinde nereye koyabileceğimizin argümanlarını destekleyecek sınıf olmadığı için Osmanlı işçi sınıfının tarihi de yazılmadı. ${ }^{12}$

Yukarıda yapılan tespitler ele aldığımız dönemi bir bütünlük içerisinde tasvir edebilmenin bazı zorluklarına değinmek içindir. Tarihin ideolojik kullanımı bize manzarayı çoğu zaman idealize edilmiş örnekleriyle veya karikatürize edilmiş örnekleriyle sunmuştur. Mesela Mardin'in ifadesiyle siyasal aktör olarak padişah yerine Mustafa Reşit Paşa'ya işaret eden Tanzimat, ordunun ve kamu hizmetlerinin Avrupalılaşmasını, uzun kaftan ve sarık giyen memurların yerine fes ve ceket giyen memurları hatırlattı. Batılılaşmanın özellikle karşıtları nazarında görüntüsü bunlardan ibaret olacaktı. ${ }^{13}$ Oysa bütün yüzyıl içinde Osmanlı tarihi açısından dünyanın diğer ülkeleriyle paralel gelişmeler oldu. Mesela modern eğitim öğretimin organizasyonu, matbaa ve matbaa ürünlerinin yoğun kullanımı bunlardandır. Matbuat olgusu sadece basın tarihinin tasnifleriyle açıklanamayacağ gibi Agâh Efendi’nin gazetesi Tercüman-ı Abvâl ile başlayan süreç sadece özel gazetenin doğuşundan ibaret olarak anlaşılamaz. ${ }^{14}$

Kısacası gazetenin, ansiklopedinin, derginin, romanın, tiyatronun edebiyat ve düşünce tarihine girişi, telgrafın tellerini kuşların konuşu, demiryollarının fotoğraflanışı, akademi kurmak, ilim yaymak, mesleği geliştirmek peşindeki meclisler, cemiyetler, ilk ve ortaöğretimin yanı sıra üniversite açma girişimleri, halkın aydınlanma ve aydının aydınlatma arzusu yoğunlaşmış, basının gelişmesiyle sansür ortaya çıkmıştır. Avrupa başkentlerinde diplomatik görevliler ve yurtdışı eğitime giden öğrenciler dışında Osmanlı aydınları yaşamaktadır. Bunlar Avrupa başkentlerinde gizlenmeye gerek kalmadan toplanabilen gazete çıkarabilen muhaliflerdir. ${ }^{15}$ Bütün bu hareketliliğin ilk görünümleri bir çeyrek yüzyıla sığdırıldığında bu zaman dilimi Kırım ve Osmanlı-Rus Savaşları (1853-1878) arasını işaret etmektedir. Bu çeyrek yüzyıl içinde 1860'lı ylllardaki canlılık sadece Türkiye ile ilgili olarak açıklanmayacak kadar farklıdır. ${ }^{16}$

\footnotetext{
${ }^{11}$ Burada kullanılan ifade Orhan Kurmuş’un Emperyaliz̧min Türkiye’ye Girişi, 3.Baskı, (Ankara: Savaş Yayınları, 1982) adlı eserine atfen kullanılmıştır. Burada kastedilen kitabın bir eleştirisi değildir, sadece dönemi birbiriyle ilişkili olguların içinden sadece birine tercih ederek açıklamanın mümkün olmayacă̆ına vurgu yapmaktır.

${ }^{12}$ Burada Dickens'a atıf edebî metnin tarihi malzeme olarak gücüne dairdir. Batıda romanın zirve yaptığı zamanda Türk romanı yeni doğuyordu. Bu açıdan dönemin hikâye edilmesi Batılı kaynaklarla kıyaslandığında Osmanlı tarihi açısından aynı imkanlara sahip olmadığı dile getirilmiştir. Thomson'un İngiliz İşçi sınıfını 18. Yüzyılın ikinci yarısında 19. Yüzyıla uzanan serüveniyle ele alırken Osmanlı devletinde işçi sınıfı kavramını oluşturacak alt yapı henüz ortada görünmüyordu. ${ }^{13}$ Mardin, age, s.9.

${ }^{14}$ Burada Türk Basın ve Yayın tarihi üzerine yapılan genel çalışmalarda görülen zaaflara dikkat çekilmek istenmiştir. Bunların çoğu kronolojik zamana oturtulan biyografi ve bibliyografik tasniflerden ibarettir. Agâh Efendi ve gazetesi sınav ve bilgi yarışmalarında kullanılabilir bir bilgi türü olarak hafızalarda kalmıştır. Yazılı eserler vermediği için bilinmesi de zor görünün ama icraatı farklı bir bağlamda ele alınmalıdır.

15 Bknz, Cavit Orhan Tütengil, İngiltere'de Türk Gazeteciliği, (İstanbul: Belge Yayınlar1 1985); Yusuf Mardin, Namı Kemal'in Londra Yillar, (İstanbul: Milliyet Yayınları, 1974).

16 “...1860’lar Rus tarihinde bir dönüm noktasıdır. Belirleyici olay II. Aleksander’’n 19 Şubat 1861'de bir fermanla serflere özgürlük vermesidir. Ancak politik ve kültürel bakımdan 1860’lar birkaç yıl daha önce, Aleksander döneminin
} 


\section{İKI HARBIN TOPLUMSAL KARŞILIĞI VE TARİH YAZIMINDAKİ YERİ ÜZERİNE}

Kırım Savaşı hem yaşanıldığı hem de sonraki yıllara etkisi anlamında üzerinde yeterince durulmamış, savaşın neticesi olarak görülen Islahat Fermanı, Tanzimat düzenlemelerini fermanla başlatan dönemselleştirme için daha tutarlı bir başlık olarak görülmüş ve dolayısıyla Kırım Savaşı ve etkilerinin gölgede kalmasındaki nedenlerden biri olmuştur. Bir bakıma Kırım Savaşı'nın çoktan unutulmuş olmas $1^{17}$ veya yeterince incelenmemiş olması savaşın, reformlara odaklanmış tarihçilerin gündeminden Islahat Fermanı lehine uzaklaşmasıyla da ilişkilidir. Islahat Fermanı, Kırım Savaşı'nın neticesidir, dolayısıyla bu süreç Kırım Savaşı'nın sonucundaki gelişmeler olarak da değerlendirilebilir. ${ }^{18} 1877-78$ Osmanl1- Rus Savaşı'na dair üretilenler ise hem yabancı hem yerli kaynaklar açısından daha çeşitli ürünler sunmaktadır. Kırım ve Osmanlı-Rus savaşlarında Osmanlı Devleti’nin ortak düşmanı Rusya'dır. Her iki savaş da ilkinde sınırlı olmak üzere özellikle ikincisinde Türkiye'nin demografik haritasında belirgin bir şekilde değişikliğin nedenlerindendir. Bu değişimin toplumsal ve siyasal etkileri Osmanlı Türkiye'sinin ve bugünkü Türkiye'nin kaderine yansiyacak şekilde uzun süreli olmuştur. ${ }^{19} 18$. yüzyıl başlarından itibaren sürekli çatışmak zorunda kalınan Rusları, Moskoflukla kavramsallaştıran düşmanlık ve savaşlar literatürde ve halkın hafızasında 93 Harbi olarak bilinen 1877-1878 Osmanlı-Rus Savaşı ile zirveye çıkmışır. Kırım’ın özlenen bir coğrafya, Ruslarınsa tarihsel düşman olarak Türk milliyetçiliği ve milli tarih yazımındaki duygusal konumlarını besleyen ideolojik imkânın sürekli üretilebilirliğinin referanslarıyla birlikte Türk halkının kolektif hafızasının dinamiklerini oluşturan bazı kanaatlerin oluşumu bu savaşların neticesinde doğmuştur. Barış zamanlarında dahi düşman metaforu olarak kullanılan “Moskof" ile kavramsallaştırılmış Rus'un Kırım’da dâhil olmak üzere Osmanlı-Rus harpleri ve ağırlıklı olarak 93 Harbi'yle şekillenen kolektif hafızadaki yeri, 20. yüzyılın ikinci yarısından sonra komünizmle mücadelenin tarihsel temellerini oluşturacaktır. ${ }^{20}$

bașlangıcında Kırım Savașı fiyaskosundan sonra Rusya'nın radikal değişmeler yașayacağının yavaş yavaș herkesçe anlaşılmasıyla başlamıştır denilebilir...”. Berman, age, s.285.

${ }^{17}$ Kırım Savaşı, savaş esnasında basın ve telgraf vasıtasıyla oldukça canlı izlenmesine rağmen İngilizler içinde unutulmuş bir savaşa dönüşmüştür. Tabii konuyla ilgili İngilizce metinlerin Türkçedekilerle kıyaslanmayacak kadar çok olduğunu hesaba katmalıyız. Bu açıdan baktı̆̆ımızda Türklerin bu savaşı unutması için İngilizlerin haklı gerekçelerine benzeyen gerekçeleri yoktur. Türklerin savaşı unutması ve bilimsel çalışmalara konu olması üzerinde ayrıca durulmalıdır. Ponting, Kırm Savaşı adlı eserinde savaşın İngilizler tarafından unutulmasını şöyle açıklıyor: "İngilizler neredeyse her bakımdan bir hezimet olduğu için Kırım Savaşı'nı unutmanın daha düşeceğine karar verdiler. Savaş bir dizi gerçek ve potansiyel olarak zararlı soruları gündeme getirmiş, ordunun komuta kademesine kaynaklık eden küçük aristokratik grubun yeterliliği, siyasi yönetici elitin kabiliyeti ve İngiliz hükümet sisteminin etkinliği hakkında kuşkular uyandırmıştı.” Clive Ponting, Kırm Savașı, (çev.) Hakan Abacı, (İstanbul: Alfa Yayınları, 2015), s.9-10.

18 Islahat Fermanı devri Enver Ziya Karal'ın Osmanlı Tarihi'nde 2 ciltte ele alınmıştır. Nizam-1 Cedit ve Tanzimat bir cillte toplanmıştır. Bu daha önce edebiyat tarihçilerini döneme ilgisi üzerinden yaptı̆̆ımız tespitin yansımasıdır. Bknz, Enver Ziya Karal, Osmanl Taribi, c 6-7, (Ankara: Türk Tarih Kurumu Yayınlar1 1983-1988).

${ }^{19}$ Bknz. Kemal H. Karpat, Osmanli'dan Günümüze Etnik Yapılanma ve Göcler, (İstanbul: Timaş Yayınları, 2010); Ayhan Kaya, Türkiye'de Cerkęler, (İstanbul: Bilgi Üniversitesi Yayınları, 2011)

${ }^{20}$ Moskoflukla kavramsallaşan Rusya ve Ruslar hakkındaki kanaatlerin kolektif hafızaya yerleşmesinde modern edebiyat ve popüler tarihin önemli katkısı olmuştur. Mesela bu alanın önde gelen isimlerinden Necip Fazıl'ın yazdığı Moskof, (İstanbul: Toker Yayınları, 1973) adlı kitapla Kadir Mısıroğlu’nun yazdığı Moskof Mezalimi, (İstanbul: Sebil Yayınları, 1970) adlı eseri yayın tarihleri itibarıyla komünizmle mücadeleyi öngören milliyetçi mukaddesatçı ideolojinin kaynaklarını beslemesi bakımından dikkate değer. Ayrıca Namık Kemal’in düşman figürü olarak Rus ve Rusya fikrinin modern edebiyatla formüle edilmesi ve toplumsal nitelik kazanmasında öncü olduğu söylenebilir. Bknz. Selahattin Çiftçi, “Namık Kemal'in Eserlerinde Rusya ve Ruslar”, İÜTAE Türkiyat Mecmuası, c. 25, sayı 1, 2015.; Popüler tarihçi Şapolyo'nun Gaz̨i Osman Paşa ve Plevne Müdaafası adlı kitab1 93 Harbi’nin popüler tarihçiler tarafindan nasıl görüldüğü açısından dikkate değer bir eserdir.“... Osmanlı İmparatorluğu’nun mukadderatı üzerinde en müessir olanı (Plevne 
Burada tarihsel süreci savaşın belirleyiciliği veya savaşların bir tarihsel zamanı ayırt etmek için bir ayraç olarak kullanılması durumunda savaşın toplumsal, siyasal ve ekonomik sonuçlarına işaret ettiğimizi belirtmeliyiz. Harp tarihi kapsamına girecek orduların organizasyonu ve karşılaşmalarını bir takım taktik ve stratejik harp manevralarını içeren bir araştırmanın içinde değiliz. Dolayısıyla bu çalışmada zaman aralığını Kırım ve 1877-78 Osmanlı-Rus Savaşları arası dönem olarak belirlediğimizde zaman dönemini anlama ve açılama girişiminde savaşların olağanüstü rolüne sık vurgu yapmaya gerek duyulmamıştır. Şüphesiz harp sonrası başlıkları harp öncesine dair manzaradan çok daha provoke edici araştırma alanları sunmaktadır. Sanki savaşın yıkıcıllı̆̆ harp öncesi dünyayı beraberinde yıkmış, sonrası ise canlılığa işaret eden berrak ve huzurlu bir alan olarak karşımıza çıkmıştır. Kültürel hayatsa canlılığın göstergelerinden biridir. Kültür tarihi çalışmanın veya savaşın kültürel etkileri üzerinden bir şey yazmanın zorluklarını dikkate aldığımızda bu zorlukların yanı sıra Türkiye'nin yakın dönemini çalışan tarihçilerin zihinsel performansının reformlarla anılan ve sürekli ilerlemeyi gösteren bir maluliyetin etkisinde olduğunu da dikkate almalıyız. 18. yüzyıldan 19. yüzyıl başlarına uzanacak şekilde yaklaşık yüz elli yıllık zaman diliminin temel paradigması reform odaklıdır. Nizam-1 Cedit, Tanzimat, Islahat ve Meşrutiyet kavramlarıyla meydan okuyucu siyasal duruşun arkasında devleti ayakta tutmak için toplumu dönüştürmenin hedeflendiği reformlar durmaktadır. Reformlar zinciriyle açıklanmaya çalışılan yakın tarihin daha doğrusu inkılâp tarihi bakışıyla kurgulanan yakın tarihçiliğin tercihi, zamanı reformlar üzerinde ilerleyen bir tarihsel sürece yükleyerek gidilecek limanı Cumhuriyet olarak belirlemiştir. Kırım Savaşı'nın küresel boyutları ve etkilerinden uzak, yakınçağ tarihçiliği genellikle bu pusulanın peşinden gitmektedir.

Kırım Savaşı sonrasındaki gelişmelerin öncesine göre fark edilir boyutu daha çok eğitim ve kültür alanında kendini gösterdi. Bunun için Kırım ve Osmanlı-Rus Savaşları arası dönem bütün yüzyıl içinde kültürel canlanmanın olağanüstü görünümlerine sahiptir. Tanpınar'ın deyişiyle "hiçbir devirde görülmemiş bir fikir gerginliği” bu dönemde görülmeye başlayacak, ${ }^{21} 1876$ ' daki ilk anayasa denemesi ve sonraki gelişmeler 1860'lı yıllarda başlayan fikir gerginliğinin doruklara ulaştığını gösterecektir. ${ }^{22}$ Matbuat bu gerginliği yansıtan ürünlerin çeşitliliğiyle dikkat çeker. Gazete, mecmua, tiyatro, roman ve bunları araç olarak kullanan aynı zamanda siyasal muhalefetin temsilcisi durumundaki aydınların ortaya çıkışı ve birlikte hareketi bu dönemi önceki dönemlerden büsbütün ayırmaya yetecek farklılı̆̆ın göstergelerindendir. Dolayısıyla Kırım Savaşı'nın edebiyata yansımasıyla 1877-78 Osmanlı-Rus Savaşı'nın yansımasındaki nitelik ve nicelik farkı olgusal çokluk ve edebi birikimden kaynaklıdır. Roman ve Tiyatro gibi Batılı türler edebiyata hâkim olmuş, şiirin dili

Savunması) olmuştu.93 Harbi adını verdiğimiz 1877 Türk-Rus Savaşı sonunda Türkler bütün Avrupa Türkiye’sini kaybedeceklerdi.” Enver Behnan Şapolyo, Gaz̧i Osman Paşa ve Plevne Müdaafasi, (İstanbul: Türkiye Yayınevi, 1959), s.3.

21 Tanpinar, age, s.161.

${ }^{22}$ Kırım Savaşı sonrası için belirleyici bir tarih olarak kullanmak istediğimiz 1860’lı yılların savaşın düşman cephesindeki aktörü olan Rusların tarihinde de bir dönüm noktası olduğunu 10 numaralı dipnotta belirtmiştik. Rusya'da belirleyici olan Kırım Savaşı'nın bir neticesi olarak II. Aleksander'in 1861'de bir fermanla serflere özgürlük vermesi olarak görünüyordu. Savaşın galiplerinin tarafında yer alan Osmanlılar için de 1860 bir dönüm noktasıdır. Altmışlı yıllar Kırım Savaşı sonrasında kültürel ve siyasal gelişmeler anlamında Rusya ile Osmanlı ülkesindeki paralellik gösterir. Nitelik ve nicelik olarak olmasa da kültürel hareketlilik ve entelektüel sınıfın doğuşu aynı tarihsel zamana karşlık gelmesi itibarıyla benzerlikler gösterir. Berman'ın şu ifadesi benzerliği görmemiz açısından referans olabilir. “ 1860’ların en önemli özelliklerinden biri yeni bir aydın kuşağı ve üslubunun doğuşuydu...) Berman, age, s.286. Osmanlı sosyal ve kültür tarihi açısından 1860 yılının kronolojik başlangıç kabul edilmesinde bu yıla diğerlerinden farklı anlam katan ilk MüslümanTürk özel gazetesinin yayımlanmasıdır. Basın ve yayın tarihi açısından önemli bir başlangıçtır ki gazeteyle öne çıkaracağımız matbuatın cazibesi Kırım Savaşı sırasında artmıştır 
değişmiş, edebi metin üretimi matbuatın gelişimiyle doğru orantılı olarak artışa geçmiştir. Kamuoyuna hitap eden muhaliflerin gazete yazıları bir külliyat oluşturmaya başlamıştır. ${ }^{23}$

Osmanlı Ordusu Kırım Savaşı'nda Sivastopol önünde eski düşmanla yeni bir askeri harekât karşısındaydı. Karşısında küffar vardı, fakat küffarın bir kısmı da kendi saflarında, üstelik İstanbul'un içinde üs kurmuştu. Harp tarihinde birçok ilklerin yaşanılacağı bir safha yaşanıyordu. Yine de Osmanlı Askeri, kuvve-i maneviyesini "kırklar ve yediler"in oluşturduğu "erenler"in yardımıyla birlikte dua vasıtasıyla sıladaki nişanlısıyla kuracağı rabıtaya bağlamıştı. ${ }^{24}$ İman, minare, gazi şehit vb gibi sembolik kavramlarla kurgulanmış bir dünyaydı cephe. Cephe dışındaki hayatın, her türlü görünümüyle devam ettiği yer ise Üsküdar'd1. O günlerin İstanbul'undan bugüne melodisi çalınmış bir beste üzerinden kâtiplerin kolalı gömleklerine söylenen kâtibim şarkısı kaldı. Mehter musikisine ait sözlerle kaybedilmiş coğrafyalarla olan bağa atıf yapılmaktadır. Mesela "Kırımdan gelen Sinan" figürü ile başlayan sözlerle aradaki bağ duygusal olarak yaşamaya devam etmektedir. ${ }^{25}$ Mehteran tarafindan "Sivastopol Marşı" olarak söylenilen türkü ${ }^{26}$ cepheyi, kâtibim türküsü ${ }^{27}$ ise Kırım Savaşı sırasındaki İstanbul'u dillendirir ve çoktan unutulmuş o günleri bugüne taşır. Artık referans olduğu, dillendirdiği tarihselliğin ve dramın bugün için tatlı bir melodi olmasının ötesinde herhangi bir toplumsal karşılığı olduğu söylenemez. ${ }^{28}$ Bu şarkının sözleri kâtipleri, feraceli kadınların görünmeyen gülümsemelerini, peçelerinin ardına gizledikleri sevdalarına gönderme yaparken esasında toplumsal değişmeye ve memurla simgeleşen devletin yeni cehresine gönderme yapmaktadır. ${ }^{29}$ Artık devletin Batıya bakan yeni çehresinde eğitimli, yabancı dil bilen, toplumsal ve siyasal gelişmelerle doğrudan veya dolaylı olarak ilgilenen askeri ve sivil memurların hâkimiyeti başlamış, maarif davası bütün problemlerin çözümü olarak onu mutlak bir inançla savunacak aydınların meselesi haline gelmiştir. Eğitim ve öğretimin bir mesele olarak sadece devletin değil aydının meselesi haline gelmeye başladığı yıllardaki kurumsal ve zihinsel değişim aşağıda ele alinacaktır.

\footnotetext{
${ }^{23}$ Mesela Namık Kemal ve ibret gazetesindeki rolü için bknz, Mustafa Nihat Özon, Namık Kemal ve İbret Gaz̧etesi, (İstanbul: Yapı Kredi Yayınları, 1997).

${ }^{24}$ Burada mehter sözlerinden alınan ifadeler sufi geleneğin üçler yediler kırklar şeklinde formüle edilen evliyaya gönderme yapan kavramlarıyla oluşmuştur.

25 "Kırımdan gelir gelirim, Adım da Sinan'dır..." mehter.com.tr/icerik.php?id=34

${ }^{26}$ mehter.com.tr/icerik.php?id=34.

${ }^{27}$ Kırım Savaşı esnasında çıkan bu türkü devrin özellikle kıyafetle ilgili görüntüsünü yansıtmaktadır. Memurların setre ve pantolon giymesi halk arasında eleştiri konusu oldu. Selimiye Kışlası İngiliz askerleri için hastane olarak tahsis edilmişti. İngiliz ordusundaki İskoç alayını kısa eteklerle gören halk bu askerlere donsuz asker lakabını takmıştı. Bir İskoçyalı bestekâr bu alayın şarka hareket etmesi sırasında bu birlik için marş besteledi. Bu müzik kullanılarak kâtiplerle dalga geçmek için kâtibim türküsü söylendi. Daha sonra çalg1lı küçük konsol saatleri çıtı. Bu saatler Türkiye’ye İskoçya'dan geldi. İskoçlar bu saatlere İskoç alayının marşını müzik olarak koymuşlardı. Bu saatler İstanbul'da Katibim Türkülü Saat adı altında satıld1. Ayrıca türkünün hikayesiyle ilgili farklı bilgilerde mevcuttur bknz. bttps://tr.wikipedia.org/wiki/Kâtibim. Reşat Ekrem Koçu'nun bu türkünün hikâyesini anlattığ1 konuşma için bknz. https://www.youtube.com/watch?v=jXcTfPgjqa0

28 “İngiliz halkı Kırım Savaşı'nı Hafif Süvari Tugayının felaketle biten kahramanca hücumu ve kendisini fedakârca hastalarına adayan Florence Nightingale'in hikâyeleriyle hatırlar. Doğru olmamasına rağmen bir gemi dolusu sol çizme teki gönderilmesi gibi efsanelere hâlâ inanılır. Ayrıca Alma ve Inkerman gibi muharebelerin meyhane veya sokaklara verilen isimleri ya da balaklava, cardigan veya raglan gibi kumaş ve elbiseler de bu savaşın yaşanmışlığını insanlara belli belirsiz hissettirir." Ponting, age, s.7.

${ }_{29}$ Mardin, age, s.9; Ebru Bayar, Kate Fleet, Osmanl İstanbul'unun Toplumsal Taribi, (çev.) Serpil Çağlayan, (İstanbul: Türkiye İş Bankası Yayınları, 2014), s.312-315.
} 


\section{BASIN VE YAYIN HAYATI}

Kırım ve 1877-78 Osmanlı- Rus Savaşları arasındaki yıllarda Osmanlı süreli yayın ve kitap üretiminin belirgin bir şekilde arttığ1 görülmektedir. ${ }^{30}$ Buna Osmanlı tebaası Gayr-i Müslimler ve yabancı basındaki hareketlilikte dâhil edilebilir. Kırım Savaşı'nın Osmanlı toplumundaki yansımaları konusunda matbuat âleminin özellikle basın konusunda modern dünyanın hızına yetişememiş olması savaşın öncesi ve sonrasında olup bitenlere dair bilgimizin sınırlarını belirlemiştir. Oysa Kırım Savaşı tarihte basın tarafından sonuna kadar ilgiyle izlenen ilk savaş olmuştur. Görsel materyallerle zenginleştirilen haberler, resimli dergi ve gazeteler vasıtasıyla yaşanmakta olan bir savaşı ülkelerindeki okuyucuya aktarmışlardır. ${ }^{31}$ Daha çok İngiltere için geçerli olan bu durumun Osmanlı Devleti'ndeki yansıması dönemin yarı resmi Türkçe gazetesi Ceride-i Havadis ten izlenmiştir. ${ }^{32}$ Bu gazeteye Kırım Savaşı sırasında gösterilen ilgi ve başka gazetenin olmaması ülkenin gazeteye olan ihtiyaca rağmen farklı nedenlerden dolayı süreli yayınlar konusundaki geç kalmışlığını göstermektedir. Vakayı haber formatında sütunlarına dizerek okurla buluşturmanın peşindeki gazeteci, gazete öncesinde kulaktan kulağa çoğalan "söylenti”ye meydan okurken söylentinin kaynağının yazılı metinle kamuya sunulan kendi tasarrufundaki "haber" olmasını arzular. Telgrafın kullanımı haberi uzak yerlere taşımak zorundaki gazeteciye mesafenin kaybettirdiği zamanı kazandırmış ve gazetenin kamuoyu önündeki gücü artmıştır. Artık olup bitenlerden olup biterken haberdar olunabilecektir. Harp sırasında basına gösterilen ilginin sürekliliği kısa zaman sonra 1860’tan itibaren özel gazetelerin birbiri ardına yayımlanmasıyla görünecektir.

1860 yılı gazetecilik için bir dönüm noktası oldu. Bu tarihle başlayan dönem öncesiyle kıyaslandığında Osmanlı matbuat hayatında büyük bir sıçrayışa işaret eder. Sanki üzeri yıllardır bilinçli bir şekilde kapatılmış matbuat, bir el tarafindan örtünün kaldırılmasıyla birdenbire hareketlilik kazanmıştır. 1860 yılı daha çok ilk Türk gazetesinin doğuşuyla hatırlanır. Bu durumda örtüyü kaldıran el Agâh Efendi’nindir. Matbuata ait yeni kurumsal yapıların ortaya çıkışı, rekabetsiz devlet gazetesi ve Ceride-i Havadis'in tekelindeki basın dünyasını renklendirmiştir. Tercüme ve telif eserlerle çoğalan kitapların da ardı ardına yayımlanmaya başladığı matbuat dünyasındaki bu canlılık, sadece süreli yayın ve kitap isimlerinin kronolojik dizimiyle açıklanabilir bir olgu değildir. Gazete ve kitap dünyası etrafindaki kurumsallaşmanın ihtiyaç duyduğu istihdam alanları, yeni bir sınıf, edebi veya siyasi türden metinlerin gündelik hayata gündelik dille ulaşma çabasi ${ }^{33}$, bu hareketlilikle beraber gelen inzibati tedbirler birbirine geçmiştir. ${ }^{34}$

Süreli yayınlarla kurulan diyalog, politik dilin sembollerini hafizalara yerleştiren popülist siyaset ve bunları kurtuluş reçetesi olarak alan okur kitlesi aydınlarla birlikte iktidara dönük kamuoyu baskısına ortak olmuşlardır. Bütün bunlar mevcut cemiyette siyasal ve toplumsal kimliği kolektif bir formda yeniden inşa ettirmenin pratikleri olarak görünmektedir. Dönemin şartlarına göre yeniden

\footnotetext{
${ }^{30}$ Bu dönemde basılan kitaplarla ilgili sayısal veriler için bknz. Jale Baysal, Osmanl Türklerinin Bastıklar Kitaplar, 17291875, 2. Basım, (İstanbul: Hiperlink, 2010), s. 54-65.

31 Clive Ponting, Kırm Savaşı, Çeviren: Hakan Abacı, 1. Basım, Alfa Yayınları, İstanbul 2015, s.12-19; Alan Palmer, Kurm Savaşı ve Modern Avrupa'nın Doğuşu, Çeviren: Meral Gaspıralı, Alfa Yayınları, İstanbul 2014, s.9-10.

32 Orhan Koloğlu, Osmanlidan 21. Yüzynla Basın Taribi, (İstanbul: Pozitif Yayınlar1, 2015), s.30.

${ }^{33}$ Gürsel Korat, Dil Edebiyat ve İletişim, 3. Baskı, (İstanbul: İletişim Yayınlar1, 2012), s.29-30; Mehmed Said Paşa, Gazateci Lisâm, Hazırlayan: Ersin Özarslan, ( Mehmed Said Paşanın hayatı, gazeteciliği ve diğer faaliyeti ile Gažeteci Lisâm adlı eserinin tahlil ve değerlendirilmesi ve eserin yeni harflerle tenkitli metni) (Ankara: Lotus Yayınları, 2007).

${ }^{34}$ Servet İskit, Türkiye'de Matbuat İdareleri ve Politikalar, (Ankara: Basın Yayın Umum Müdürlügü Yayınları, 1943), s.10; Fatmagül Demirel, II. Abdülhamid Döneminde Sansür, (İstanbul: Bağlam Yayınları, 2007), s.30.
} 
inşa edilen cemiyet milliyetçilik teorilerinde ileri sürülen hayâlı bir topluluğa doğru dönüşmektedir. Matbuat bu dönüşümün en önemli aracıdır. ${ }^{35}$ Gazetenin yaygınlaşmas1, olayların olup biterken haber vasfiyla kapalı kapıların arkasına girecek gücü, romanlarda hayat bulan milli kahramanlarını kitap aralarında taşıyan ve onlarla diyalogu, bireysel okumanın henüz yaygınlık kazanmadığı bir zamanda toplu ve sesli okuma yoluyla kuran okurla buluşturması, aynı zamanda hayali topluluğun birbiriyle buluşması olacaktır. Hiçbir zaman birbiriyle tanışma üzerinden kurulmayacak diyaloglarryla bu topluluğun bireyleri kolektif muhayyile üzerinden mistik bir haz duyacaklardı. 19 . ve 20.yy.larda entelektüelleri ve entelektüel alanı meşgul eden millet fikri hızlı bir şekilde yayılmaya başlarken, milletin dinle olan ilişkisi İslamcılık, Osmanlıcılık, milliyetçilik gibi kavramların içinde yeniden formüle ediliyordu. ${ }^{36}$

Gazetenin gündelik hayatla olan ilişkisi dil üzerinden kurgulanabilirdi. Yazılı dilin, taşbasmalarına konu olan metinleri dışında kalanların gündelik hayatın esas aktörleri olan halkla ilişki kurabilmesi zordu. Mazmunlara sığınarak mistifiye olmuş, edebi sanatlarla süslenmiş ve tarihsel süreç içerisinde dışarıdan aldığı kelimelerle çoğalmış yazı dilinin halk karşısındaki çaresizliği dilin sadeleşmesini beraberinde getirecekti. Nihayet, bu devirde dilde sadeleşme esas hedefi kitle olan gazeteyle gündelik hayata girecekti. ${ }^{37}$ Artık dış dünyayla ilişki başka bir gözle izlenmeye başlanmıştır. Tanzimat ve Islahat Fermanlarının teklif ettiği reformlar yalnızca bir devlet programı olmaktan çımış, kamuoyunda paylaşılır hale gelmiştir. 1826-1840 arasında doğanlar kendi nesillerinin meseleleri üzerinde o zamana kadar görülmemiş bir şekilde durmuşlar ve bu meseleleri gazete vasıtasıyla halkın arasına "agora"ya taşımışlardır. Böylece kısa zamanda ortaya, hadiseleri daha yakından ve daha bilinçli bir şekilde takip eden bir kamuoyu oluşmaya başlamıştır. ${ }^{38}$

\section{SÜRELİ YAYIN VE MATBU KITTAP YAYINCILIĞININ YÜKSELİŞİ}

Avrupa'da matbu kitabın doğuşundan yaklaşık yüz elli yıl sonrasında ilk gazete örnekleri görünmeye başlamış ${ }^{39}$, fakat gazetecilikte devrim denilebilecek gelişmeler 19. yüzyılda olmuştur. Basının bu yüzyılda dikkat çekici şekilde gelişmesinde birçok faktör bulunmaktadır. Her şeyden önce eğitim alanındaki yenilikler, okuryazarlık oranlarının yükselmesi, kentli nüfusun yoğunlaşması ve dolayısıyla müşteri sayısının artmasıyla ilgilidir. İletişsim ve ulaşım araçlarının gelişimi bilgi ve yayının dağıtımında etkili olmuştur. Bunun yanı sıra kâğıt yapımı, basım makineleri ve dizgi makinelerindeki yeniliklerin bir araya gelmesi göz ardı edilmemelidir. Basının ilerleyişinde 19. yüzyılın sonlarına doğru reklâmın önemli katkısı olmuştur. Tefrika, haber, anekdot, dedikodu ve gündelik hayatın sorunları paylaşıldıkça gazeteyle halk arasındaki diyalog sempatik bir ilişkiye dönüşmüştür. ${ }^{40}$

\footnotetext{
35 Anderson, Hayali Cemaatler adlı eserinde milliyetçilik teorisini matbaa kapitalizmi üzerine oturtur. Bknz. Benedic Anderson, Hayali Cemaatler (çev.) İskender Savaşır, (İstanbul: Metis Yayınları, 2015).

${ }^{36}$ Bknz. Karpat, Islamm Siyasallaşmasi, age.

${ }_{37}$ Niyazi Berkes, Türkiye'de Çăgdaşlaşma, (İstanbul: Doğu-Batı yayınları, 1978), s. 255-261; İbrahim Şahin, Ahmet Hamdi Tanpinar-Haz ve Günah, 2.Basım (İstanbul: Kap1 Yayınlar1, 2012), s.49-50. Korat, age, s.29-30.

38 Tanpinar, XIX. Asır Türk Edebiyatı...s.162-163.

${ }^{39}$ Peter Burke, Bilginin Toplumsal Tarihi, Çeviren: Mete Tunçay, 4. Basım, (İstanbul. Tarih Vakfi Yurt Yayınlar1, 2013), s.184-185: Ayrıca Avrupa'da ilk gazete örnekleriyle ilgili bknz, M. Nuri İnuğur, Basın ve Yayın Taribi, 5.Basım, (İstanbul: Der Yayinlar1, 2005), s.55-86.

401865 y1lında " Le Petit Journal 260 bin satyordu-1892 de bir milyon. Albert Labarre, Kitabın Taribi, (çev.) Galip Üstün, (İstanbul: İletişim Yayınları, 1994), s.119; Süreli yayınların Türkiye'deki görünümü için bknz, Uygur
} 
Gazetecilikle ilgili yüzlerce yıllık Batı tecrübesini hazır bir form olarak bulup taklit eden Osmanlı Basını'nın ilk ürünlerinin tıpkı matbaanın kuruluşu ve matbu kitap yayıncılı̆̆ında olduğu gibi toplumsal bir heyecanla karşılandığına dair bir belirti yoktur. Ancak ilk devlet gazetesi ve yarı resmi gazetesinin çağın hızlı akışına göre oldukça uzun süren tekelciliği son bulup özel yayıncıllğın ürünleri birbiri ardına ortaya çıkmaya başladığında artık toplumsal heyecan uyandıracak birikimin oluşmaya başladığ1 söylenebilir. Birçok konuda ilklerin yaşandığ1 1860’lı yıllarda ilk örnekleri merkezde görülen modern kurumlar taşrada da yapılanmaya başlamıştır. Devlet gazeteciliği ve yayıncllı̆ı̆nın merkezdeki rolü vilayetlerde kurulan matbaalarla taşraya taşınmıştır. Devlet teşebbüsü olarak yayıncılık, salnameler ve vilayet gazeteleri aracılı̆̆ıyla bütün Osmanlı topraklarına yayılırken, sonraki yıllarda bazı vilayet merkezlerinde özel matbaa, kitapçllı, yayıncıllk ve gazetelerin doğuşunun da zeminini hazırlamıştır. Bu zemin modern eğitimin taşrada kurumsallaşmasıyla paralel gelişmiştir. $^{41}$

1860' ta yayımlanmaya başlayan Agâh Efendi'nin sahibi olduğu Tercüman-ı Abvâl, Takvim-i Vekâyi ve Ceride-i Havadis gibi resmi ve yarı resmi gazetelerin tekeline son vermiş, gazeteciliği resmi ve yarı resmi sıfatlarından kurtaran yeni bir çığır açmıstır. Bundan sonraki süreçte gazete artık gündelik hayatın bir parçası haline gelecektir. Basın yayın organlarındaki hareketlilik beraberinde bütün çağdaş ülkelerde olduğu gibi basın üzerindeki kontrolü sağlayan bir nizamnameyi beraberinde getirmiştir.(1864) ${ }^{42}$ Gazete yayıncıllğıyla basın üzerindeki kontrol birbirine paralel gelişme göstermiştir. Bu nizamname çıkarıldığında ilk Türkçe gazete Takvim-i V akayi otuz, Ceride-i Havadis yirmi dört, Tercüman-ı Abvâl ve Ruzname-i Ceride-i Havadis dört, Tasvir-i Efkear üç, Ceride-i Askeriye iki ve ilk Türkçe dergi sayılan Vakayi-i Tıbbrye on beş, Mecmua-i Fünûn ile Mirat iki, Mecmua-i Askeriye bir seneden beri yayınlanıyordu. Kısacası süreli yayınlar açısından neredeyse yolun başlangıcıydı. Erken dönemde başlayan yabancıların Osmanlıdaki gazete yayıncıllğı ve azınlıkların çıkardığ1 gazetelerin Türkçe basına oranla bu yıllarda daha güçlü olduğu bilinse de, mevcut bilgiler bu gazetelerin nüfuz alanı konusunda yeterli analiz yapabilecek imkân vermemektedir. ${ }^{43}$

Gazete sayısının artışına paralel olarak matbuat hayatında dergiler de görünmeye başlamıştır. Batı'nın Osmanlı'yı uzun yıllardır cezbeden özelliği bilim ve tekniğiydi. Batı'nın tekniğine ve bilimine olan ilgi dönemin gazete ve dergilerinin sayfalarından takip edilebilir. Batının bu cazibesi üzerinden misyon üstlenmiş cemiyet ve bunların yayın organı dergiler, batıdaki bilimsel ve teknik gelişmeleri imkânları ölçüsünde Osmanlı okuyucusuna tanıtmaya çalışmışlardır. İlk Türkçe dergi Vakâyi-i Təbbiye 1849-1851 arasında 28 sayı olarak yayınlandı. "Vaka" tabiri takvim-i vakadan alınmış olmalı sonraki yıllarda dergilerin birçoğu Batı fennini ifade eden "fünûnu" ad

Kocabaşoğlu, “Türkiye’de Matbuatın “Zuhuru” Üzerine Gözlemler” Yakın Türkiye Tarihinden Sayfalar, Sina Aksin Armağanı, Hazırlayan: Mehmet Ö. Alkan, (İstanbul: Türkiye İş Bankası Kültür Yayınları, 2014), s. 113-132.

41 Bkz. Hasan Duman, Osmanl Türk Süreli Yaynlar ve Gazeteleri (1828-1928), (Ankara: Enformasyon ve Dökümantasyon Hizmetleri Vakf1, 2000); Hasan Duman, Osmank Salnameleri ve Nevsalleri I-II, 2. Bask1, (Ankara: Enformasyon ve Dokümantasyon Hizmetleri Vakfı, 2000); Bülent Varlık, "Yerel Basının Öncüsü: Vilâyet Gazeteleri”, Tanz̧imat'tan Cumburiyet'e Türkiye Ansiklopedisi, c.I, (İstanbul İletişim Yayınları, 1990), s.99-102; Taşrada eğitim için bknz. Somel, Osmanlida Eğitimin Modernleşmesi, age.

${ }^{42}$ Demirel, age, s.32. Bu kanun Fransız basın kanunundan esinlenerek yapıldı. Orhan Koloğlu, Osmanlidan Günümüze Türkiye'de Basın, 2.Baskı, (İstanbul: İletişim Yayınları, 1994), s. 42.

43 İskit, age, s.15: Azınlık ve yabancıların çıkardığı gazete sayıları için bkz. Kocabaş, agm. 
olarak kulland1. ${ }^{44}$ Mecmua-ı Fünûn, Rebber-i Fünûn, Hað̧ine-i Fünûn, Servet-i Fünûn gibi isimlerle çıkan süreli yayınlar aynı zamanda batı fenni karşısında duyulan ilginin tezahürüydü. Özellikle I. Meşrutiyet sonrasında Ahmet Mithat geniş kitlelere ulaşıp okuma alışkanlığının gelişmesinde büyük katk1 sağladı. Romandan tarih kitaplarına kadar her alanda yazan Ahmet Mithat'ın Dağarcık adıyla çıkardığı dergisi bu işlevi yerine getiren önemli bir araçt. Bu dergi Mecmua-i Ulûm'un halkın daha iyi anlayacağı dilde yazılmış şeklidir. Avrupa bilim ve felsefesiyle İslâm arasında çözüm arayan Ahmet Mithat, Kuran ve hadisten yola çıkarak Batı düşüncesiyle benzerliklerin peşindeydi ${ }^{45}$ Dergilerde kurtuluş arayışları bundan sonraki dönemlerde artan ölçüde gelişir. Osmanlıcıllğın savunucusu, Mecmua-i Eburziya 1880'de yayınlanmaya başlar ve 159 sayı olarak yayınlanır. ${ }^{46} 1870$ 'li yllarda Terakki, Basiret, İbret, Hakayikülvakayi Devir, Siraç, Hülasatü'l-fikir, Şark, Hayal, Bedir gibi gazetelerin yanı sıra Diyojen, Cingrraklı Tatar gibi mizah gazeteciliğinin ilk örnekleri de vardı Dönemin yaygın ve gözde kavramı olan "fünûn” un süreli yayınlar üzerindeki etkileyiciliği zaman içerisinde daha da güçlenen politik dilin gölgesinde kalmaya başladı. Böylece fen yoluyla Batı'nın bilimsel kapısını açan dergilerin popülerliği, yerini yine Batı fikirlerinden etkilenmiş siyasi mesaj veren dergi ve gazetelerin üstünlüğüne bırakacaktı. Gazetenin siyasal muhalefetin aracı haline gelmesi beraberinde sansürü de getirdi. Yasakların çoğalması ve yazarlar üzerindeki baskının artmasıyla Avrupa'nın bazı şehirleri Osmanlı muhalif basını için adres haline geldi. ${ }^{47}$

Türkiye'de ilk özel gazete, fikir ve basin özgürlüğü düşüncesi, sansür gibi kavramların eş zamanlı olarak doğuşu yukarıda verilen bilgiden anlaşılacağı üzere 1860'lı yıllarda oldu. Burada özel teşebbüsün ürünü olarak gazetenin iktisadi imkânlanını gelişkin bir ekonomik yapıyla ilişkilendiremeyiz. Aynı şekilde hürriyet kavramının politik dilin ana unsurlarından biri haline gelmesine rağmen siyasal ve toplumsal referanslarının henüz yeni tartışlmaya başlandığı bir ortamda fikir ve basın özgürlüğünün sınırları da berrak değildir. Basının tarihsel arka planın zayıflı̆ı onu bir ithal ve taklit edilen ürün olmanın ötesine taşıyamamıştır. Gazetenin muhatabı ağırlıklı olarak aydınlar ve memurlardı. İstanbul'un sinırları aşması zaman alacaktı. Sadece haber ve siyasi meseleler değil gazeteler edebiyat ortamının önemli bir parçası oldular. İlk gazeteciler aynı zamanda ilk edipler, ilk siyasi muhalifler olarak tanındılar. Siyasi fikirler bile fikrin orijinalliği ve gücünden ziyade edebi üslubun sığınağında göze çarpar hale gelmişlerdir. Şinasî, Ziya Paşa, Namık Kemal, Ebuzziya Tevfik, Ahmet Mithat basın kadar edebiyat tarihinin aktörleridirler. Gazete, edebiyat, fikri ve siyasi hayat iç içe geçmiştir. ${ }^{48}$ Gazetenin yükselişi matbu kitap yayıncllı̆̆nda da kendini göstermiştir.

1727'de Müteferrika matbaasıyla başlayan Osmanl1-Türk matbaacılığının ilk yüzyılında ciddi bir külliyat oluşturacak yayıncılık faaliyeti görülmedi. Yaklaşık yüz yıl sonra matbaada basılan kitap sayısı iki yüzü bulmamıştı. Basılanların büyük çoğunluğu ise 19. yüzyılın ilk çeyreğinde açılan matbaaların ürünüdür. İlk Osmanlı Türk matbaası bir devlet teşebbüsüydü ve matbaacilık 19. yüzyılın ikinci yarısına kadar uzun bir süre böyle kaldı. El yazması kültürüne bağlı kurumlar,

${ }^{44}$ Bknz. Zafer Toprak, "Fikir Dergiciliğinin Yüzyılı", Türkiyede Dergiler Ansiklopediler, (İstanbul: Gelişim Yayınları, 1984), s. 13-18.

${ }^{4}$ Zafer Toprak, agm, s.15-16: Bknz, Orhan Okay, Batı Medeniyeti Karşısında Ahmet Mithat Efendi, (İstanbul, Milli Eğitim Bakanlığ1 Yayınları, 1989).

46 Toprak, agm, s.17.

${ }^{47}$ Bknz. Koloğlu, Osmanlidan Günümüre, age, s. 53.; Cavit Orhan Tütengil, İngiltere'de Türk Gazeteciliği, (İstanbul: Belge Yayınlar1 1985); Yusuf Mardin, Namık Kemal'in Londra Yillar, (İstanbul: Milliyet Yayınlar1, 1974).

48 İskit, age, s.55-56. 
istihdam alanları, ürünleri matbaanın ilk yüzyılında matbaanın varlığından etkilenmediler, ancak bir asır sonra yazma eserlerin yeri matbu eserlerle değişmeye başladı. Böylece sadece kitaplar değil kitapla ilgili kurumlarda da değişmeye başladı. Mesela 19.yüzyllın ilk yarısına gelindiğinde o güne kadar yazma kitap satan sahafların ilgisini pek çekmeyen matbu kitaplar tömbeki dükkânlarında satılmıştı. Yıllarca el yazmalarını alıp, satan sahaflar önceleri matbu kitaba pek sıcak bakmazken, kısa bir süre sonra yayıncılığa da adım attılar. ${ }^{49}$

Matbaanın gelişip yaygınlaşması daha çok pratik ihtiyaçlarla ilgili kitapları gündeme sokmuştu. Halka hitap eden kitaplarsa ürünlerini daha kolay basan ve ucuza mal edebilen taş basmacilığın keşfiyle önemli bir mesafe kat ettiler. Mektepler, yükseköğretim, gazete, dergi derken Batı'nın edebi türlerinin girişi, tercüme faaliyetleri, okuryazarllğın buna paralel gelişiminin bir göstergesiydi. Edebi türlerin tiyatro, roman ve tercüme faaliyetleriyle zenginleşmesi 1850 'lerde başlamış, altmışlı yetmişli yıllarsa büyük bir sıçramanın görüldüğü dönüm noktası olmuştu. İçi fenle doldurulmuş ecnebi kitaplarının bir neslin yabanc1 dil bilgisinin ötesinde tercümeyle yaygınlaştırılması gerekiyordu. Bir anlamda Hilmi Ziya'nın uyanış devirlerinde tercümeye ${ }^{50}$ atfettiği rol bu dönemde yeniden ortaya çıtı. 1862'den itibaren yayımlanmaya başlayan Jules Verne'in kitapları yabancı dillere en çok çevrilen Fransız yazar olarak sonu gelmeyen bir başarıya imza attığında Türk matbuatında fark edilir bir hareketlilik görünmeye başlamıştı. Matbaanın icadından kısa bir süre sonra Yahudiler vasıtasıyla tanıdıkları matbaayı Müslüman Osmanlılar ancak iki buçuk asır sonra kullanmaya başladılar. Bu kullanımın da lütfen olduğu ancak yüzyılı aşkın bir zaman sonraki yayın patlamasıyla daha iyi anlaşılabilir.

Kitap basımı 1860’lı yıllarda bir on yıl öncesine göre iki katına çıtı. 1840-1858 yllanı arasında 799 kitap basılmıştı. Batıdan ilk edebi çevirilerin yapıldığı 1859-1868 arasında ise 537 kitap basıldı. Bu yıllar geçmişle mukayese edildiğinde basım sayısının ikiye katlandığını göstermektedir. 1869-1875 arasında ise 1179 kitap basılmıştır ki bu sayı yaklaşık yüz elli senelik Osmanlı kitap basımındaki gelişmeyi göstermesi bakımından dikkate değer bir veridir. ${ }^{51}$ Şüphesiz edebi türlerin çeşitliliği tercüme veya telif eserlerde kendisini göstermesi nicelik olarak yayınlara yansımıştır. Roman, tiyatro gibi türlerin halka dönük etkisi ve halkın bu türlere karşı teveccühü kitap basımını artırmıştır. Kitap basımı sayısının artışında eğitim organizasyonunun modernleşmesiyle ilgili ihtiyaçlar, edebi türlerin yeni vasıflarına uygun şekilde yükselişi, modern fikirlerin tartısılma zemini, tarihçiliğin dönüşmeye başlaması, etkiler arasında düşünülmelidir. Bunların yanı sıra 1846' dan beri yayımlanan devlet salnamelerine vilayet salnameleri de katılmış bu da çeşitliliği artırmıştır. ${ }^{52}$ Divan edebiyatın ürünleri hem Bulak hem de İstanbul'daki matbaalarda basılı esere dönüştürülmeye 1840 yıllardan itibaren başlamıştı. Batı edebiyatı 1858-1880 arasında sadece tercüme yoluyla değil Türk edebiyatının yönünü değiştirecek temeller atıldı ve ilk ürünler verilmeye başlandı. Batının yüzlerce yıllık roman yazımı birikimi Osmanlı tecrübesinde kısa bir doğum sancısıyla ortaya çıkmıştır. Bunun yanı sıra sözlük yayıncıllğı da kayda değer artış göstermiştir.

\footnotetext{
49 İskit, age, s. 34.

${ }^{50}$ Hilmi Ziya Ülken, Uyanıs Devirlerinde Tercümenin Rolü, (İstanbul: Türkiye İş Bankası Kültür Yayınları, 2011).

${ }^{51}$ Baysal, age

52 Salnameler için bkz. Hasan Duman, Osmanl Salnameleri ve Nevsalleri I-II, 2. Bask1, (Ankara: Enfermasyon ve Dökümantasyon Hizmetleri Vakfi, 2000).
} 
$\mathrm{Bu}$ dönemin pek zikredilmeyen ama sembolik değeri itibarıyla matbu kitap alanındaki üzerinde ayrıca durulması gereken en önemli gelişme Kuran'ın basılmasıdır. Kuran daha 16. yüzyılda Avrupa'da 19. yüzyılın hemen başında Kazan'da olmak üzere yine bu yüzyıl içine Müslümanların yaşadığı Hindistan ve Mısır gibi yerlerde basılmıştı, Osmanlı matbaasında Kuran basılması ise bunlarla kıyaslandığında oldukça geç dönemdir. ${ }^{53}$ Batı'da basılan ilk kitabın kutsal kitap olması Osmanlı'da ise kutsal kitabın basılmasının yasak olması her iki dünyanın zihni yapısını bunun matbaa, kitap kültürüne yansımasını göstermesi bakımından anlamlıdır. Modern okulun ve yükseköğretimin yeniden yapılanması beraberinde ders kitabı ve kaynak kitap niteliğindeki eserlere duyulan ihtiyacı artırmıştı. Ele aldığımız dönemde kitap baskısının artışında ders kitaplarına olan ihtiyaç önemli bir yer tutar.

\section{OSMANLI AYDINI VE ENTELEKTÜEL ALANI}

Entelektüel, münevver, aydın; birbirlerinin yerine kullanılan üç kavramın etimolojik çözümlemeleri bu kullanımların göründüğü kadar birbiriyle örtüşmeyecek sonuçlar doğurabilir. Buna rağmen üç kavramın birbirinin yerine kullanılmasının sakıncaları ancak anlamı sürekli zorlaştırma çabasıyla ortaya çıkabilir. ${ }^{54}$ Bir tarihçi için Cemil Meriç'in sorduğu "Kim bu ıntelijansiya" sorusu oldukça açıktır, fakat sorunun açıklığı söz konusu olan Osmanlı aydını olduğu zaman cevabı aynı derecede kolaylaştırmaz. "Münevver ve aydın" kavramlarının çağrıştırdığı tipoloji kavramların kendi tarihselliğiyle bütünleşmiş durumdalar. Bizim sorumuz Tanzimat devri Osmanlı aydını üzerine olduğunda araştırma alanımız gazeteci ve edip kimlikleriyle sınırlarına sığacak şekilde daralmaktadır. Bilim ve felsefenin hâkim olduğu Batı dünyasında edebiyat zirvesine ulaşan eserler verirken, Osmanlı ülkesinde taklidi edebiyat ilk örneklerini bilim ve felsefenin olmadığı bir entelektüel zeminde veriyordu. Bu zeminde edebi metinler ve yeni doğan aydın sınıfın Batılı kelimelere karşılık araması ve siyasal alanı dizayn ederek memleketi içinde bulunduğu durumdan kurtarmak için kullandığı kavramlar bulunuyordu. Hürriyet, medeniyet, meşrutiyet, şura, müsavat, adalet, vatan gibi kavramlar dönemin aydınının kavramsal haritasını gösterirler. ${ }^{56} \mathrm{Bu}$ kavramların devri incelemek gerektiğinde karşımıza Namık Kemal'i tek seçenek olarak tercih etmemizi gerektiren sağlam dayanakları vardır.

Osmanlı Entelektüel hayatı ve aydını üzerine yapılan araştırmaların bize çok dilli veya harfli yazılı metin üretimine açık bir kültür hayatının birbiriyle olan diyalogunu, araçları, ürünleri, kurumları, sınırları ve aktörleriyle ortaya koyacak derecede yeterli literatürü oluşturduğunu

\footnotetext{
${ }^{53}$ Kuran basımı için bknz, Mahmut Gündüz, Matbaanın Tarihçesi ve İlk Kuran-1 Kerim Basmaları, s.344-348. acikerisim.fsm.edu.tr:8080/xmlui/bitstream/ handle/11352/1256/Gündür.pdf?sequence..

54 “Entelektüel” sözcüğünün Fransızcadaki kaynağ1 olan intellectuel, düşünce ve kültür ürünlerine büyük ilgi duyan bunlardan tat alan, zihinsel yaşantısı ağır basan kişi anlamına geliyor. Dilimizde aşağı yukarı aynı anlamda kullanılan ve 20. Yüzyılın başlarında ortaya çıkmış olan "münevver" ve daha sonra onun yerini almaya çalışan "aydın” sözcükleri de var. Okumuşluğu, önyargılardan sıyrılmış eleştirel düşünce ve hatta görgü sahibi olmayı da içeren bu iki sözcük, ilk ve temel anlamında ele alındığında intellectuel'den değil de Fransızca eclaire'den (aydınlanmış)kaynaklanmış gibi görünüyor" Selahattin Hilav, Entelektüeller ve Eylem, Hazırlayan: Sema Rifat, 2. Baskı, (İstanbul: Yapı Kredi Yayınları, 2016)

55 Hilav, Rusça'da kullanılan ve 1920'li yıllarda Fransızcaya da geçmiş olan intelligentsia (entelijensiya) kelimesinin Rusya'dan gelen soydaş aydınlar tarafından münevver şeklinde kullanıldığı fikrindedir. 20.yüzyıl başlarında kullanılan "fırka-i münevvere"nin anlamı sadece bilgi kültürlü insan anlamına gelmemektedir. Toplumsal ve siyasal sorunlara ilgi duyan ve çözüm getirmek amacıyla etkinlik gösteren kişileri kapsaması bakımından Rusçada kullanılan anlamıyla aynidir., age, s.11

${ }^{56}$ Şerif Mardin, Sabri Ülgener, Niyazi Berkes, Hilmi Ziya Ülken, Kamiran Birand ve daha birçok ismin ilgi alanı entelektüel tarihin araştırılabilir bir alan olmasında öncü katkıları olmuştur.
} 
söyleyemeyiz Bu yargımızın referansı çok dil ve kültürlülügün bir arada ama birbirine dokunmadan yaşadıklarını düşünmemizi gerektiren metinlerdir. Akabi Hikâyesi'nin hikâyesi bu kültürel hareketliliğin içerisinde birbirine dokunmadan ortaya çıtını düşündüğümüz metinlerin hikâyesiyle iç içedir. Daha önce Namık Kemal örneğinde görüleceği üzere entelektüel alan edebiyat ve edip kimliğinin tasarrufundadır. Bu dönemin Osmanlı aydını istisnalar haricinde gazeteciyi, şairi, romancıyı hatırlatır. Araştırmalarda özellikle edebiyat tarihçileri ve tarihçiler reformların kutsi kronolojik çizgisi üzerinden Mustafa Reşit Paşa'nın Şinasîye uzattığı el onun Namık Kemal'e bıraktığı miras ve devam eden bir silsile üzerinden iyileşmeye doğru giden bir sürekliliğin izlerini takip etmektedir. ${ }^{57}$

Dönemin birçok ismi arasında esas aktör tartışmasız Namık Kemal'dir. Onu "vatan ve hürriyet" kavramlarının esas mucidi ve şairi olarak tanımlamak yeterli bir argüman olarak sunulabilir. ${ }^{58}$ Şüphesiz Şinasî ve onun selefi Namık Kemal'in devirlerini alt üst eden zihinleri değiştiren hayata yeni ufuklar açan ve birlikte giriştikleri birkaç yıllık mücadelenin sonunda cemiyetin ruhu ve insan manzarası eskiden farklı bir hale gelmeye başlamıştı. ${ }^{59}$ Namık Kemal'in vasıtasıyla sadece üzerinde doğulup büyünmüş toprak parçası olmaktan çıkarılan vatan oldukça büyük ve parçalanma tehlikesiyle karşı karşıya kalmış bir ülkeye işaret ediyordu. ${ }^{60} \mathrm{Bu}$ ülkenin sınırları resmi olarak muhayyel değildi, siyasi coğrafyanın işaret taşlarıyla çevrilmişti; fakat vatanseverin vatana ve onun sınırlarına dair bilgisi henüz epistemolojik olarak aydınlanmamıştı. ${ }^{61}$ Modern edebiyatın bütün unsurları artık bu aydınlatmayı sağlayacak bilginin yayılması için kullanılacaktı. Mesela dönemin sembolik eseri "Vatan yahut Silistre"62 aydınlatmanın aracı olarak dikkat çeken örneklerden biridir. Bu eserin bir tiyatro oyunu, tiyatro edebiyatının gelişimin bir

\footnotetext{
${ }^{57}$ Edebiyat alanında bu çok kültürlüğü yansıtan bir çalışma için bknz. Tanzimat ve Edebiyat-Osmanl İstanbulu'nda Modern Edebi Kültür, (haz.) Mehmet Fatih Uslu, Fatih Altuğ, (İstanbul: Türkiye İş Bankası Yayınlar1, 2014). Ayrıca Mehmet Fatih Uslu, Catıșma ve Müzakere-Osmanlida Türkçe ve Ermenice Dramatik Edebiyat, (İstanbul: İletişim Yayınlan1, 2014).

58 “'Hersekli Arif Hikmet'in evinde toplanan Encümen-i şuara'ya devam ettiği yıllarda gazelleri henüz ortaya çımış, devrin şairleri arasında görünmeye başlamıştı. Eski edebiyatın bütün söyleyişs sırlarına aşina ve yeteneği çevresinde takdir görmüş bir şairdi. Memleketin haleti ruhiyesi değişmiş, yenilik arzusu hayata hakim olurken gençlerin çoğu ufkun öte tarafında sezilen bir alemin hasretini çekmeye başlamıştı. Şinasî ile tanışması onun mecrasını belirledi." Bir nefeste denecek kısa bir zaman içinde tamamladığı divânını değilse bile, onun esas nescini veren eski mazmunları kapadı; sırrî lûgatı tekellüm etmeği bıraktı, biraz da içinde uyuyan mücadeleci kuvvetlerin gizli itilişiyle yeni bir ifade şeklinin adamı oldu." Cemiyete kendisini adarken ne istediğini bilen bir cemiyet ve mücadele adamı olacaktı. Avrupa'yı yakından tanımaya çalıştı, bunun için hukuk, iktisat, edebiyat gibi alanlarda incelemeler yapmıştı. Devrinin en büyük şöhreti olan Victor Hugo'yu ve belki o kanalla Shahespeare’i okumuştur. Tiyatrolara gitmiş tiyatro eserlerini mütalaa etse de Batı sanatlarının hepsiyle ilgilenmemiştir. Kendisinin musikişinaslığı olduğuna dair pek işaret yoktur. Onu Avrupa'nın daha ziyade gündelik hayatı, iktisadi durumu ve refahı, idari yapısı gibi şeyleri alakadar etmiştir. Batı felsefesiyle hemen hiç alakası yoktur denilebilir. Devrinin yolsuzluklarını affetmeyen, fikirleri aydınlatma ve uyandırmak gayesindeki bir mücadeleye gazetelerdeki yazılarıyla devam etti. $\mathrm{O}$ artık siyasi kanaatleri olan bir herhangi adam değil yaşadığı cemiyeti değiştirmek ve mukadder felaketinden kurtarmanın çarelerini tam ve eczası birbirine sıkıca bağlı bir sistem halinde anlatan vazıh fikirli bir mürşit olacaktı. Onun siyasi akidelerinin teşekkülünde vatan endişesi esastı ve her an yıkılma tehlikesi içinde yaşarken sadece bireysel özgürlüklerin peşinde olamazdı. Bu paragraf Ahmet Hamdi Tanpınar, 'In “ Namık Kemal'’in Hayatı ve Eserleri”, Edebiyat Üzerine Makaleler, (İstanbul: Dergâh Yayınları, 1969), s.236-260, adlı eserinden özetlenmiştir.

${ }^{59}$ Tanpınar, "Namık Kemal'e Dair Düşünceler”, age, s.226.

60 “...Yine meselâ $V$ atan kelimesinin eski mefhumunu unutturup ona Fransız inkılabından sonra Avrupa'da verilen yeni mefhumu verdi. O zamandan beri kelime Türkçe'nin siyasiyatta ve hayatta en fazla telaffuz edilmiş kelimelerinden biri sayılır...” Yahya Kemal Bayatlı, “Nâmık Kemal'e Dair”, Edebiyata Dair, (İstanbul, 1971), s.281. ${ }^{61}$ Vatan kavramının mevcut anlamından çıkarllıp siyasal bir coğrafya olarak formüle edildiği ilk yıllarda bu kavramın
} tam olarak ne anlama geldiğinin hem aydınlar hem de halk arasında henüz tam olarak anlaşılmış olduğu söylenemez.

${ }^{62}$ Namık Kemal, Vatan Yâhut Silistre, Hazırlayan: Kenan Akyüz, 2.Baskı, (Ankara: Kültür Bakanlığ1 Yayınları, 1988), Akyüz’ün kitabın giriş kısmında değerlendirme yazısı vardır. 
parçası, Namık Kemal'in izleyenleri büyülemiş bir eseri veya siyasal ve fiziki coğrafyaya gönderme yapmasının ötesinde daha fazla anlamı olduğu argümanı bize iki savaş arası devri açıklayabilmek için bir hareket alanı sunmaktadır.

Tiyatro edebiyatı Batılaşmanın ürünü olarak doğmuş yeni bir türdü. Bu türün gücünün farkında olan aydının, tiyatro metinlerini uyarlama ve kurgulama konusunda melekeleri hizlı gelişmiştir. Türk aydını kısa zaman önce örnekleri görülmeye başlayan Batılı bir türde orijinal eser verebilmekte, bu türün sahnelendiği mekânları da aşacak şekilde toplumsal karşılık bulabilmektedir. Vatan Yahut Silistre doğduğu şartlardaki kültürel bağlamın çözümlenmesi ve dönemle ilgili birçok ayrıntıyı görmemizi sağlayacak bir eserdir. Eser bize ilk bakışta sınırları yüzlerce yıl boyunca geriye çekilmek zorunda kalan dramatik bir coğrafya ve asırlardan beri bu coğrafyayı ele geçirmeye çalışan bir düşmana "Ruslara ve Rusya"ya işaret eder. Yeni doğmakta olan entelektüel zihnin ürettiği politik anlamıyla vatan kavramına, kahramanların vatanseverlik idealizmiyle bütünleşen dünyalarına, gazete tefrikasına, oradan okura, tiyatro sahnesine, izleyiciye, halka, sokağa, muhalefete, iktidara, sansüre, sürgüne götürür. Yalnız Islahat Fermanı'nın uygulanmasıyla açıklanmayacak kadar renkli bir dönemin ürünü olan bu eser zamanın aynası olduğu kadar, tarihselliğinden çıkarak gelecek zamanların işlevsel bir metin olarak popülaritesini bugüne ulaşacak kadar sürdürecektir.

Eskiyle olan farkllğı belirgin şekilde görülmeye başlayan cemiyet, bu cemiyetin içinde bireyin yeri ve aradıkları nedir? Eskisinden farklı olduğu gözle görülecek bir manzara vardır. Bu durum İngiliz askerinin İstanbul hastanelerinde tedavi olması veya Fransız askerlerinin sokak aralarına yansıyan anlaşılmaz dillerinden çıkarılacak didon tipolojisinin öyküsünün, ya da Didon Arifin Kuleli vakasındaki isyancı rolünün ötesinde bir yerdedir. ${ }^{63}$ Hakikati aydınlatmayı "Barika-i hakikat müsademe-i efkârdan doğar" deyimiyle fikirlerin çatışmasında bulan bir zamana gelinmiştir. Bu çatışma en güzel şekliyle Ahmet Hamdi'nin dönemi ifade etmek için kullandığ1 "hiçbir devirde olmadığı kadar olan fikir gerginliği” ile tanımlanabilir. Gazete vasıtasıyla bilinenleri bir vakalar zincirinin ötesine taşımanın zamanı gelmişti. Takvim-i Vekayi veya Ceride-i Havadis hatta daha önce bahsi geçen Vakayi-i Tıbbrye adlı derginin adındaki "vaka" kelimesinin gösterdiğinin dışında fikirleri taşıyacak süreli yayınlara ihtiyaç doğdu. Mevcut süreli yayınlar değişen cemiyeti aydınlatma konusunda yeterli değildirler. İşte bu ihtiyaç zorunlu hale geldiğinde, yani hale tercüman olacak bir gazete arandığı sırada Tercüman-ı Abvâli yayımlamak için Agâh Efendi ${ }^{64}$ yayıncı olarak çıktı. Mevcut cemiyet bir tek kaynağın vereceği haberle tatmin olmayacak kadar değişmekte olan insanları barındırıyordu. Yeni fikirlerin birbiriyle olan karşılaşması süreli yayın talebini artırdı. Tasvir-i Efkâr bu taleplerin arasında doğmuştur. Adına bugüne ulaşan zincirde münevver denilen aktörlerin kamusal alanda buluşması gazete vasıtasıyla büyük bir hız kazanmıştır.

Aydının siyasal alana hâkimiyeti ve cemiyeti biçimlendirme isteği bütün dünyada olduğu gibi Osmanlı aydınının da tutkuyla sarıldığı bir arzuydu. Üzerinde oluşan sis perdesiyle bugün bile ezoterik anlama biçimleri geliştiren Kuleli Vakası dışında bir hareketliliğin görülmediği 20. Yüzyılın ortalarında Osmanlı başkentini Avrupa'yı sarsan sosyal hareketler etkilememişti. Yine de entelektüelin meydan okumasını ve kendisine biçtiği rolü sahneleyebileceği mekânlar ve araçlara ihtiyaç vardı. Konaklar ve mahfiller bunun için zamanın ruhuna göre yeniden şekillenmiş meslekî

63 Kayahan Özgül, Divan Yolu'ndan Pera'ya Selametle, (Ankara: Hece Yayınları, 2006), s.90.; Mardin, Yeni Osmanlı Düsüncesinin..., s.236-238.

${ }^{64}$ Server İskit, Hususi İlk Gaz̧etemiz Tercüman-ı Abvâl ve Agâh Efendi, Ankara 1937. 
ve ilmî cemiyetlerin yanı sıra gizli cemiyetler doğmuştu. Cedîd kavramının tarihsel yürüyüşünün durduğu, yerini medeniyet ve terakki kavramlarına bıraktığı, yeninin "Yeni Osmanlıları" ve fikirlerini çağrıştırdığı bir zamana gelinmişti. Bu dönemde Yeni Osmanlılar ve bu hareketin öne çıkan isimleri entelektüel hayatın aktörleri olarak karşımıza çıkmışlardır. Yeni Osmanlılar hareketi birçok etkinin ürünü olmasına rağmen onun entelektüel temelleri bir kişi üzerinde toplanmışır. $O$ kişi 19. yüzyılın ortasında Avrupa'ya hâkim olan sosyal ve siyasal kavramlarla Türk aydınlarını tanıştıran Şinasî Efendi’ydi. ${ }^{65}$ Namık Kemal ${ }^{66}$ kendi ifadesiyle yeni Osmanlıların entelektüel üstatlı̆̆ını ona dayandırır. Tanpınar'ın deyişiyle dışarıdan gelen baskının sonucu gibi görülen ıslahat fermanı iç politikanın dizaynında ve ortaya çıkacak ihtilallerini hazırlayıcısı durumundadır. Bu fermanla yeni bir nesil, "çok acele ve acemice olsa bile" ilk defa kendi adlarına konuşmaya başlamışlardır. ${ }^{67}$ Gazete mevcut ve doğabilecek problemleri kamuoyuyla paylaşmaktadır. Memlekette hiçbir devirde görülmemiş fikir gerginliği bu tarihten sonra başlayacak, bugüne kadar gelen farklı ideolojilerin temelleri o dönemde atılacaktır. Tanzimat'ın medeniyetçilik anlayışı, Osmanlıcılık, İslamcılık bugünlere kadar yansımaları görülen ideolojidir. ${ }^{68}$

Aydının toplumsal sorumluluğu vatan üzerinde yaşayanlar lehine bir tasarrufu gerektirir. Vatan gibi bu vatanda yaşayanlar da modern bir formülasyonla tanımlanmalıdır. Aydın milleti tarihsel anlamında koparı yeniden tarif etmek için modern kavramları ve algıy kullanır. Halk kitlesi artık bir milletin bilinçlendirilmiş mensupları ve siyasal kimliğiyle öne çıkan bir topluluğa dönüşmelidir. Bilim Mecmua-i Fünûn'la, fikir dönemin gazeteleriyle, eğitim-öğretim modern okullarda vücut bulacaktı. Batının bilimi, taklit, teklif etmenin ve hayranlık beslemenin dışında Osmanlı aydınını meşgul edecek kadar somutlaşmamış, bilimle ilişki henüz duygusal düzeyde kalmıştır. Bundan dolayı bilime dair bilinenler ancak modern gündelik hayata ait pratikler sunacak taklidi bilgiden ibaret olabilirdi. O devir İstanbul'unda bilim bir bilgilenme ve bilineni bilmesi gerekenlere kendi dillerinde aktarma çabasıydı. Bir laboratuvara vakfedilmiş hayatların yokluğu, sadece labaratuar yokluğuyla ilişkili açıklanamayacak kadar uzun hikâyedir. Dolayısıyla yeni bilimsel keşif veya icat haberlerinin duyulması gazetelerde ve ancak tercüme yoluyla olacaktı.

1850’li yıllardan önce daha çok teknik ihtiyaçları karşılamaya dönük tercümelerin 1850'li yılların sonundan itibaren özellikle Batı edebiyatı ağırlıklı olmak üzere artışta geçtiği bilinmektedir. $\mathrm{Bu}$ artışın arkasında Tanzimat reformlarıyla birlikte eğitim-öğretimin yeniden organizasyonu çerçevesinde ele alınan konulardan birinin tercüme meselesi olması ve kurulun bir heyetle birlikte tercüme faaliyetinin resmi politika haline gelmesi vardır. Ethem Pertev Paşa, Ali Suavi, Şinasî, Ziya Paşa, Kemal Paşazade Said Bey, Recaizade Ekrem, Abdülhak Hamit, Ahmet Mithat, Yusuf Kamil Paşa, Ahmet Vefik Paşa, Münif Paşa gibi meşhur yazarların telif eserlerinin yanı sıra tercümelerinin dönemin entelektüel hayatına önemli katkıları olmuştur. ${ }^{69}$ Batıllış̧ma serüvenin yazımında temel

\footnotetext{
${ }^{65}$ Şinasî için bkz. Kaya Bilgegil, Şair Şinasî, Hal Tercümesi Üz̧erine Kü̧̧йk Bir Araşttrma, (İstanbul 1972). Birand, Aydinlanma Devri Devlet Felsefesinin Tanżimatta Tesirleri, (Ankara: Ankara Üniversitesi İlahiyet Fakültesi Yayınları, 1955), s.25.; Ziyad Ebuzziya, Şinasi, Hazırlayan: Hüseyin Çelik, (İstanbul: İletişim Yayınlar1, 1997); Bedri Mermutlu, Sosyal Düsünce Taribimizde Șinasi, (İstanbul: Kaknüs Yayınları, 2003)

${ }^{66}$ Namık Kemal’ile ayrıntılı ilgili ayrıntılı bilgi için bknz. Mithat Cemal Kuntay, Namık Kemal I-III, (İstanbul: Türkiye İş Bankası Kütür Yayınları,2010)

${ }^{67}$ Tanpinar, XIX. Asır Türk Edebiyatı Taribi, , s.158.

68 Tanpinar, age, s.159-160.

${ }^{69}$ Hilmi Ziya Ülken, İslam Medeniyetinde Tercümeler ve Tesirler, (İstanbul: Şirketi Mürettebiye Matbaas1, 1948), s.361363. Fransizca edebi tercümeler için bknz. Cevdet Perin, Tañimat Edebiyatında Fransız Tesiri, (İstanbul: İstanbul Üniversitesi Edebiyat Fakültesi Basımevi, 1946). M. Kaya Bilgegil, Ziyâ Paşa Üzerinde Bir Araştırma, (Erzurum:
} 
eserlerden biri olarak görülen Terceme-i Telemak'ın çevirisi 1859'da yapılmış, tefrika olarak yayımlanmıs, kitap olarak ise 1861(62)'de basılmıştır. Fenelon'un Yunan mitolojisinden esinlenerek yazdığı bu eser Yusuf Kamil Paşa tarafından tercüme edilmiş, özellikle Namık Kemal-Ekrem nesli üzerinde tesir etmiştir. Dönemin temel çevirilerinden sayılan Münif Paşa'nın Mubâverat-ı Hikemiye adlı tercümesi de Telemak'taki ahlaki değerler üzerinde 1srarla durur. Şinasî Tercüme-i Manzume 'de Lamartine, Musset, Hugo ve Racine'den alınmış münferit beyit ve mısraları tercüme ederek Türkçe okurla buluşturmuştur. ${ }^{70} \mathrm{Bu}$ eserler sadece bir tercümeden ibaret kalmamış, ilk olmaları dolayısıyla Batı'ya açılan bir kap1 olmuşlardır. Şinasînnin Batılılaşma anlamındaki misyonu düşünüldüğünde onun tarafindan yazılmış veya tercüme edilmiş bir eserin devrin genç entelektüelleri için muhakkak okunması gerekli bir kitaba dönüşmesi muhakkaktı. Ayrıca Şinasî, Batı şiiri ve edebiyatı tercümesinden sonra Şair Evlenmesi adlı piyesiyle Batı edebi türlerinden birinde ilk Türkçe telif eseri de yazdı. ${ }^{71}$

Klasik edebiyat 18. yüzyılın sonlarına doğru Şeyh Galib’i çıkaracak kadar güçlüyken o yıllarda teknik yönleriyle kabul görmüş Batı’nın edebiyatına henüz teslim olunacak bir manzara oluşmamıştı. Galip'in dili de devrin tarihçisinin dili de eski dilin devam niteliğindeydi, fakat Batıdan gelen kelimeler çoğalıyordu, kelimelerle birlikte anlam arayışı artıyordu. Ancak Tanzimat sonrasında değişen ve değişmesi teklif edilen dil yeni edebiyatı taşıyabilir eski edebiyattan ayırabilirdi. Geçiş devrinde yabancı dil bilenlerin yaygınlaşması ve tercüme faaliyeti dikkat çekiyordu. Batıdan yapılan edebi çeviriyle, edebi türlerin ve edebi dilin değişime uğramaya başladığı zaman birbiriyle örtüştü. Telifin hangi usuller dairesinde yapılacağı, hangi edebi metnin değişmekte olan yeni cemiyete hitap edeceğinin cevabı da Batıdan gelen haberlerin içindeydi. Batı'da ve Rusya'da romanın zirveye ulaştığ1 dünya edebiyatının en meşhur eserlerinin yazıldığı yıllarda, Türkçe roman yeni doğmuştu. Entelektüelin dönüştürmeye ve kurmaya çalıştığı ideal cemiyetin kurgulandığ1 barınaktı roman. Ahmet Mithat'ın ideal cemiyeti ancak bu romanların içinde kendine gerçek bir alan bulabildi. Romandan ziyade tiyatro, Vatan Yabut Silistre örneğinde görüleceği üzere yazıll metinden sahnenin etrafinda büyüyen mekâna, mekândan sokaklara taşarken bir siyaset pratiği olarak algılandı. Aydının halk üzerinde oluşturabileceği büyüleyici nüfuz tiyatroyla herkese açık bir şekilde hissediliyordu. ${ }^{72}$ 1860-1880 arasında birçok tiyatro eseri yazıldı. Batı'da yüzyıllardır sahnelenen tiyatronun Osmanlı topraklarındaki ilk görünümü değildi bu yıllardaki tiyatro faaliyetleri, ${ }^{73}$ fakat tiyatronun Türkler tarafından kullanımı ve siyasal güce dönük gösteriminin ilk görünümüydü ve bu işleviyle tiyatro Vatan Yabut Silistre ile sembolleşti.

Şair Evlenmesi seyirlik oyunlarımızla batı tiyatrosunun birleştirildiği komedidir. 1859’ yazılsa da 1860 yılında Tercüman-ı Abvâl de yayımlanır. ${ }^{74}$ Tanpınar 1839'dan 1860'a kadar meydana gelen

Atatürk Üniversitesi Yayınları, 1970; Yakınçağ Türk Kültür ve Edebiyatı Üzerine Araştırmalar I:Yeni Osmanlılar, (Erzurum: Atatürk Üniversitesi Yayınları, 1976).

${ }^{70}$ Tanpınar, XIX. Asır Türk..., , s.157; Ülken, Türkiye'de Că̆das..., s.79; Perin, age, s.209

${ }^{71}$ Batılalaşma ve Türk Edebiyatı için bknz, Orhan Okay, Batılılaşma Devri Türk Edebiyatı, 4. Baskı, (İstanbul; Dergah Yayınları, 2014); Tanpınar, XIX. Asır Türk Edebiyatı Taribi..., İsmail Habip, age; Özgül, age;

${ }^{72}$ Namık Kemal, "Mukaddeme-i Celal”, Yeni Türk Edebiyatı Antolojisi, (haz.) Mehmet Kaplan, İnci Enginün, Birol Emil, c.2, (İstanbul: Marmara Üniversitesi Yayınları, 1993), s.348-349.; Namık Kemal fikirlerini yayma konusunda tiyatronun önemli bir araç olduğunu görmüş ve bunu kullanmıştır. Tiyatronun gücünü şu şekilde ifade eder: “ Bir güzel oyun okumak, oynandığı görmek kadar lezzet vermese bile yine roman mütalaasına müreccahtır. Çünkü oyunda hissiyat daha şiddetli tasvir olunur..." Age, s.349.

${ }^{73}$ Tanpınar, XIX. Asır Türk, age, s.155-156; Giyasettin Aktaş, “Tanzimat Devri Türk Tiyatrosu”, Türk Edebiyatı Taribine Bir Bakıs, (ed.) M. Kayahan Özgül, (Ankara: Kurgan Yayınları, 2015), s.75-96.

${ }^{74}$ Tanpinar, age, s. 210 . 
gelişmeleri yorumlarken yeni şirin oluşması ve yaygınlaşması için zuhur eden ortamı değerlendirir. Buna göre 1839'dan sonra eski ve yeni bir arada hayatın hemen her sahnesinde bir tezatlar yumağ1 halinde iç içe yaşar. Reşit Paşa ve çevresinin çabalanı, kalemlerin tesisi, Encümen-i Dâniş gibi kurumların açılması, gazetecilik ve tiyatro alanındaki gelişmeler ve yeni şiirin filizlenip dal budak salacağı vasatı hazırlar. ${ }^{75}$ Yeni şiirin ilk büyük temsilcisi İbrahim Şinasî Efendi' dir. Yeni manzumede; sadelik, yenilik, akılcılık özellikleriyle yeni bir dilin peşinde olmuştur. Eskinin hayal sistemini reddetmiş, yeni hayal sistemi aramış, yeni bir kafiye anlayışı üzerinde düşünmüş, yeni bir şiir şekli ve yeni kavramlar konusunda büyük değişiklikler gerçekleştirmiştir. Tanzimat şiirindeki muhteva ve tematik yapının en önemli özelliği şiirlerin sosyal hayata reel olarak yakınlaşmasıdır. Yeni şiirin ilk temaları Şinasî'de medeniyet, hak, adalet, kanun, devletle milletin karşıllıklı hak ve ödevleri gibi toplumsal unsurlardır. ${ }^{76}$

Tanzimat döneminde gerek şiiri, tiyatrosu, romanı ve diğer eserleri ile ve gerekse kültür değerlerinin zaman içinde yorumlanmasına vesile olan faaliyetleri ile en büyük etki Namık Kemal'den gelir. Namık Kemal'de değişmenin ilk belirtileri gazetecilikle görünmüsstür. Entelektüel hayatı bir bütün olarak tasavvur ettiğimizde edebiyat referanslı bir mütefekkir kimliğiyle karşılaşıllır. Aydın şair, romancı, gazeteci kimlikleriyle öne çıkmaktadır. Bu türlerin arasında tiyatro yazarlığı bir kimlik ifadesi olarak diğerleri kadar öne çıkarılmaz. Tiyatronun bugün dahi toplumsallaşamadığı bir toplumda tiyatro yazarlı̆̆ yazarın diğer kimliklerinin arka planında kalması tabiidir. Bu dönemin aydında felsefeden ve bilimden yana asrın diliyle söylenecek kendilerine ait düşünceleri olmadığ1 aşikârdır. Bunun için hukukçu-tarihçi Ahmet Cevdet Paşa, Münif Paşa ve diğerleri ancak bulundukları cemiyetin içinde öne çıkmalarını gerektiren nedenlerle anlaşılabilirler, dünyaya söyleyebilecekleri bir şey olduğu söylenemez. Cemil Meriç’in değişiyle bu dönemde "fikir hayat1 gündelik gazetelerin elindedir ve bu biraz da yok demektir. Romancı arada mutavassıt olmadığı için her şeyi kendi yapmak zorundadır." 77 Mesela tarih araştırmaları yeterli olmadığı için romancı Namık Kemal örneğinde görüleceği üzere tarih yazmaya da koyulmuştur. Ortaçağdan seçtiği kahramanları vatanın parçalanmasını engellemek için argümanlarına tarihsel arka plan olarak kullanmıştır.

Aydınlar, zabitler, memur adayları, hukukçular, hekimler vs. entelektüel hayatın içinde ancak meslekleriyle birlikte var olabilenler Mesleklere daha çok diploma sağlamaya çalışan okullar ve Fransızca bilmenin büyük firsatları doğmuştu. ${ }^{78}$ Osmanlı aydınının yabancı dille olan teması onun zihinsel formasyonunun da belirleyicilerindendi. Bugün dahi akademik ve mesleki dünyasında tercih nedeni olan yabancı dil öğrenme arzusunun temelleri Tanzimat sonrasına dayanmaktadır. 1860’lı yıllara gelindiğinde artık Fransızca eğitimlilerin arasında roman kahramanlarının da bileceği kadar yaygınlaşmış, Fransız edebiyatına yakınlık tercümeler ardından taklitler yoluyla artmıştır. Avrupa ile temaslar artık resmi daire salonlarının dışına taşmıştı. Fransızca ve Avrupa'yı bilen roman kahramanı esasında gerçek hayatta aranan ideal tipti. Roman kahramanı olarak görünen ideal tipin gerçek hayattaki karşıllığ olan aydının Batı bilgisi ona kendi toplumun dönüştürme firsatı verecek bakış açısı kazandırdı. Aydının misyonu modern iletişim araçlarını ve ideolojik formları kullanarak bireyi ve toplumu dönüştürmekti. 1860'lardan sonra filizlenmeye başlayan basın ve yayınlanan kitapların çoğalması bilgiyi yaymaya yardım ederken, aynı zamanda İslamcılığın hızla yayılmasında

\footnotetext{
75 Tanpınar'ın dönemi değerlendirmeleri için bknz, , age, s.137-157.

76 Tanpinar, age, s. 196-197.

77 Cemil Meriç, Kırk. Ambar, c. 1, 17. Bask1, (İstanbul: İletişim Yayınları, 2015), s.327.

78 Meriç, Kırk Ambar, c.2, 6. Baskı, (İstanbul: İletişim Yayınları, 2014), s.139.
} 
hayati bir rol oynayacaktır. ${ }^{79}$ Aydınların yeni ve eskisinden daha çeşitli bilgi kaynaklarına doğrudan ulaşabilmesi onlara halka nüfuz etme konusunda bir iktidar alanı sağladı. Mesela romanda Rakım Efendi'de müşahhaslaşan ideal tip, Fransızca bildiği gibi İslami bilimleri de öğrenmişti. Doğuyu okumuş, bunun yanı sara kimya, anatomi, coğrafya, tarih ve batı edebiyatına da aşinaydı. Ansiklopedik bilginin kişiyi mütebahhirleştiren yapısı kendisini Ahmet Mithat da kendisini gerçek bir şahıs olarak göstermişti. Uyumsuzluk, yetersizlik ile dikkat çeken Felatun Bey'de birleşen alafranga tip, batılı olmanın kolay yolunu seçmişti. Batıyı şık giyinmek, Beyoğlu'nda eğlenip gösteriş yapmak olarak anlayan züppenin karakteristik özelliği müsrif ve tembel olmasıdır. Avrupa’yı kendisine has bir şekle sokan bu tip kendi toplumunun kültüründen de uzaktadır. ${ }^{80}$

\section{SONUÇ}

Kırım ve 1877-78 Osmanlı- Rus Savaşları arasındaki yirmi beş yıllık dönemi ele aldığımız bu çalışmanın ağırlık noktasını birçok alanda ilkin başlangıcı olan 1860’lı yıllar oluşturdu. Daha çok ikinci el kaynaklar kullanıldı. Matbuat ve Aydın üzerine ayrılan bölümlerle kültür hayatının birbiriyle bağlantılı iki unsuru genel manzarayı gösteren bir resmin içine sokulmaya çalışıldı. Kullanılabilecek verilerin çokluğuna rağmen seçici olmamı, öncelikli olarak sembolik eser, kurum ve aktörler durmamızı gerektirdi. Bu dönemde entelektüel hayatı oluşturan atmosfer edebi türler ve ediplerin tasarrufundaydı. Dönemin şiir yazmayan aydını belki yoktu ama hepsi şair olarak tanınmadı. Aydınların ağılıklı olarak şairlerden oluşmasından Osmanlıdan Cumhuriyet'e müktesebat anlamında daha da gerileyerek tevarüs eden bu şair-mütefekkir geleneğinin coşkulu dünyasındaki tefekkürün derinliği ve sığlığı konusunda bize ipuçları vermektedir. Bunun için entelektüeli Ahmet Cevdet’ten veya Münif Paşa'dan daha çok Namık Kemal ve onun eseri üzerinden görmemizi gerektiren haklı nedenler vardır. Mesela kavramlar konusunda Namık Kemal'in pozisyonu hepsinden önce gelir. Aydının ürettiği, halka ulaştığı ölçüde çoğalır. Ziya Paşa, Şinasî uzun uzadıya zikredilmesi gereken isimlerdendi, fakat çalısmanın sınırları bir makaleyi geçmeyecek kadar olmalıydı. Üstelik çok daha fazla yazılabilecek şey olan olguları bir başlı̆̆a sığdırıp aralarında korelesyonu kurabilmek buradan anlamlı bir metin çıarmak da zor oldu. Dönemin zabit sınıfı üzerindeki etkisini, sonraki yıllarda resmi mesleki yayınların dışında yayın yapan, fikir beyan eden, muhalif siyasal örgüt ve mahfillerde bulunacak gayri resmi asker yazarların doğuşuyla ilişkilendirecek doğrudan zabitlere odaklanmış çalışmalara ayrıca ihtiyaç bulunmaktadır.

\footnotetext{
${ }^{79}$ Karpat, İslamm Siyasallaşması, s.187.

${ }^{80}$ Tanpınar, XIX. Asır Türk Edebiyatı..., s.448-450.
} 


\section{KAYNAKÇA}

Aktaş, Giyasettin. “Tanzimat Devri Türk Tiyatrosu”, Türk Edebiyatı Taribine Bir Bakış, (ed.) M. Kayahan Özgül, Ankara: Kurgan Yayınları, 2015.

Akyüz, Kenan. Encümen-i Dâniş, Ankara 1975.

Anderson, Benedict. Hayali Cemaatler (çev.) İskender Savaşır, İstanbul: Metis Yayınları, 2015.

Arslan, Ali. Darülfünûndan Üniversiteye, (İstanbul: Kitabevi Yayınları, 1995).

Bayar, Ebru ve Fleet, Kate. Osmanl İstanbul'unun Toplumsal Taribi, (çev.) Serpil Çağlayan, İstanbul: Türkiye İş Bankası Yayınları, 2014.

Bayatlı, Yahya Kemal. “Nâmık Kemal'e Dair”, Edebiyata Dair, İstanbul, 1971.

Bayly, C.A. Modern Dünyanm Doğussu, (çev.) M. Neva Şellaki, İstanbul: Ayrıntı Yayınları, 2014.

Baysal, Jale. Osmanh Türklerinin Bastıkları Kitaplar, 1729-1875, 2. Basım, İstanbul: Hiperlink, 2010.

Berkes, Niyazi. Türkiye'de Çăgdaşlaşma, İstanbul: Doğu-Batı yayınları, 1978.

Berman, Marshall. Katı Olan Her Şey Buharlaşıyor,18. Baskı, (çev.) Ümit Altuğ-Bülent Peker, İstanbul: İletişim Yayınları, 2016.

Bilgegil, M. Kaya, Şair Şinasî, Hal Tercümesi Üz̧erine Küçük Bir Araştırma, İstanbul: 1972.

Bilgegil, Kaya. Ziyâ Paşa Üzerinde Bir Arasstrma, Erzurum: Atatürk Üniversitesi Yayınları, 1970;

Bilgegil, Kaya. Yakınçăg Türk Kültür ve Edebiyatı Üzerine Araștırmalar I: Yeni Osmanlılar, Erzurum: Atatürk Üniversitesi Yayınları, 1976.

Birand, Kamuran, Aydmlanma Devri Devlet Felsefesinin Tanzimat'ta Tesirleri, Ankara: Ankara Üniversitesi İlahiyat Fakültesi Yayınları, 1955.

Burke, Peter, Bilginin Toplumsal Taribi, Çeviren: Mete Tunçay, 4. Basım, İstanbul: Tarih Vakfı Yurt Yayınlar1, 2013.

Charle, C. ve Verger, J., Üniversitelerin Taribi, (çev.) İsmail Yerguz, Ankara: Dost Kitapevi Yayınlar1, 2005.

Ponting, Clive. Kırm Savaşı, (çev.) Hakan Abacı, 1.Basım, İstanbul: Alfa Yayınları, 2015.

Çiftçi, Selahattin. "Namık Kemal'in Eserlerinde Rusya ve Ruslar", İ̈TAE Türkiyat Mecmuası, c. 25, Say1 1, 2015.

Demirel, Fatmagül. II. Abdülhamid Döneminde Sansür, İstanbul: Bağlam Yayınları, 2007.

Duman, Hasan. Osmanl Salnameleri ve Nevsalleri I-II, 2. Bask1, Ankara: Enformasyon ve Dokümantasyon Hizmetleri Vakfi, 2000.

Duman, Hasan. Osmanl Türk Süreli Yayznlar ve Gazeteleri (1828-1928), Ankara: Enformasyon ve Dokümantasyon Hizmetleri Vakfi, 2000.

Engelhardt, Edouard-Philippe. Tan₹̨imat ve Türkiye, Mütercim: Ali Reşad, Yayına Hazırlayan: Akın Bedirhan, İstanbul: Kaknüs Yayınları, 1999.

Engin, Vahdettin, Mekteb-i Sultanî, İstanbul: Yeditepe Yayınları 2016. 
Gencer, Bedri, İslam'da Modernleşme(1839-1929),1. Bask1, Ankara: Lotus Yayınevi, 2008.

Gündüz, Mahmut. "Matbaanın Tarihçesi ve İlk Kuran-1 Kerim Basmaları”, V akııflar Dergisi, Say1: 121978.

Hilav, Selahattin. Entelektüeller ve Eylem, Hazırlayan: Sema Rifat, 2. Bask1, İstanbul: Yap1 Kredi Yayınlar1, 2016.

İnuğur, M. Nuri. Basin ve Yayzn Taribi, 5.Basım, İstanbul: Der Yayınları, 2005.

İskit, Server. Hususi İlk Gazetemiz Tercüman-ı Abvâl ve Agâh Efendi, Ankara 1937.

İskit, Türkiye'de Matbuat İdareleri ve Politikalar, (Ankara: Basın Yayın Umum Müdürlüğü Yayınları, 1943.

İsmail Habip. Tanæimat'tan Beri I-II, İstanbul: Remzi Kitapevi, 1940-42.

Karal, Enver Ziya. Osmanlı Taribi, c.5, 6. Baskı, Ankara: TTK Yayınları, 1994.

Karal, Enver Ziya. Osmanlı Taribi, c 6-7, Ankara: Türk Tarih Kurumu Yayınlar1 ,1983-1988.

Karpat, Kemal H. İslam'ın Siyasallaşması, (çev.) Şiar Yalçın, 5. Baskı, İstanbul: Timaş Yayınları, 2013.

Kaya, Ayhan, Türkiye’de Cerkesler, İstanbul: Bilgi Üniversitesi Yayınları, 2011.

Kayaoğlu, Tacettin. Türkiye’de Tercüme Müesseseleri, İstanbul: Kitabevi Yayınları, 1998.

Kısakürek, Necip Fazıl. Moskof, İstanbul: Toker Yayınları, 1973.

Koçu, Reşat Ekrem, bttps:/ / wmw.youtube.com/watch?v=jXcTfPgjqaO.

Koloğlu, Orhan. Osmanlidan Günümüzze Türkiye'de Basın, 2.Baskı, İstanbul: İletişim Yayınları, 1994.

Koloğlu, Orhan. Osmanlidan 21. Yüzynla Basm Taribi, İstanbul: Pozitif Yayınları, 2015.

Kocabaşoğlu, Uygur, “Türkiye'de Matbuatın “Zuhuru” Üzerine Gözlemler” Yakın Türkiye Taribinden Sayfalar, Sina Akşsin Armağam, Hazırlayan: Mehmet Ö. Alkan, İstanbul: Türkiye İş Bankası Kültür Yayınları, 2014.

Korat, Gürsel. Dil Edebiyat ve İletișim, 3. Baskı, İstanbul: İletişim Yayınları, 2012.

Kuntay, Mithat Cemal. Namık Kemal I-III, (İstanbul: Türkiye İş Bankası Kültür Yayınları, 2010.

Labarre, Albert. Kitabın Taribi, (çev.) Galip Üstün, İstanbul: İletişim Yayınları, 1994.

Mardin, Yusuf. Namık Kemal'in Londra Yillar, İstanbul: Milliyet Yayınlanı, 1974.

Mardin, Şerif. "Tabakalaşmanın Tarihsel Belirleyicileri: Türkiye'de Toplumsal Sınıf ve Sınıf Bilinci”, Türkizye'de Toplum ve Siyaset, (ed.) Mümtaz'er Türköne-Tuncay Önder, 4.Bask1, İstanbul: İletişim Yayınları, 1994.

Mardin, Şerif. Yeni Osmanl Düşüncesinin Doğuşu,( çev.) Mümtaz’er Türköne-Fahri Unan-İrfan Erdoğan, 10.Bask1, İstanbul: İletişim Yayınları, 2012.

Mehmed Said Paşa, Gaz̨eteci Lisân, Hazırlayan: Ersin Özarslan, Ankara: Gazi Üniversitesi İletişim Fakültesi, 2008.

Meriç, Cemil. Kırk Ambar, c. 1, 17. Baskı, İstanbul: İletişim Yayınları, 2015.

Meriç, Cemil. Kırk Ambar, c.2, 6. Baskı, İstanbul: İletişim Yayınları, 2014. 
Mermutlu, Bedri. Sosyal Düş̈nce Taribimizde Şinasi, İstanbul: Kaknüs Yayınları, 2003.

Misıroğlu, Kadir. Moskof Mezalimi, İstanbul: Sebil Yayınları, 1970.

Namık Kemal. "Mukaddeme-i Celal”, Yeni Türk Edebiyatı Antolojisi, (haz.) Mehmet Kaplan, İnci Enginün, Birol Emil, c.2, İstanbul: Marmara Üniversitesi Yayınları, 1993.

Namık Kemal. Vatan Yâbut Silistre, Hazırlayan: Kenan Akyüz, 2.Baskı, Ankara: Kültür Bakanlı̆̆1 Yayınları, 1988.

Okay, Orhan. Batı Medeniyeti Karşısında Abmet Mithat Efendi, İstanbul: Dergah Yayınları, 2008.

Okay, Orhan. Batıllaşma Devri Türk Edebiyatı, 4. Baskı, İstanbul: Dergah Yayınları, 2014.

Ortaylı, İlber. İmparatorluğun En Uæun Yüzynl, İstanbul: Timaş Yayınlar1, 2013.

Osmanh İlmi ve Mesleki Cemiyetleri, 1. Milli Türk Bilim Tarihi Sempozyumu, 3-5 Nisan 1987, (ed.) Ekmeleddin İhsanoğlu, İstanbul: İstanbul Üniversitesi Edebiyat Fakültesi Basımevi, 1987.

Özgül, Kayahan. Divan Yolu’ndan Pera’ya Selametle, Ankara: Hece Yayınları, 2006.

Özon, Mustafa Nihat. Namık Kemal ve İbret Gazetesi, İstanbul: Yap1 Kredi Yayınları, 1997.

Palmer, Alan. Kırm Savaşı ve Modern Aurupa'nın Doğussu, Çeviren: Meral Gaspıralı, İstanbul: Alfa Yayınları, 2014.

Perin, Cevdet, Tanzimat Edebiyatunda Fransız, Tesiri, (İstanbul: İstanbul Üniversitesi Edebiyat Fakültesi Basımevi, 1946).

Sarı, Nil. "Cemiyet-i Tibbiye-i Osmaniye ve Tıp Dilinin Türkçeleşmesi Akımı", Osmanlı İmi ve Mesleki Cemiyetleri, 1. Milli Türk Bilim Tarihi Sempozyumu, 3-5 Nisan 1987, (ed.) Ekmeleddin İhsanoğlu, İstanbul: İstanbul Üniversitesi Edebiyat Fakültesi Basımevi, 1987.

Sassoon, Donald. The Culture of The Europeans, From 1800 To The Present, London: Harper Press, 2006.

Somel, Selçuk Akşin. Osmanlida Eğitimin Modernleşmesi (1839-1908), İstanbul: İletişim Yayınları, 2010.

Şahin, İbrahim. Ahmet Hamdi Tanpınar-Hazvve Günah, 2. Basım, İstanbul: Kap1 Yayınları, 2012.

Şapolyo, Enver Behnan. Gaz̧i Osman Paşa ve Plevne Müdaafası, İstanbul: Türkiye Yayınevi, 1959.

Şişman, Adnan. Galatarasay Mekteb-i Sultanîsi'nin Kuruluşu ve İlk Ĕğitim Yullar (1868-1871), İstanbul: İstanbul Üniversitesi Edebiyat Fakültesi Basımevi, 1989.

Tanpınar, Ahmet Hamdi, “Namık Kemal”in Hayatı ve Eserleri”, Edebiyat Üzerine Makaleler, (İstanbul: Dergâh Yayınları, 1969), s.236-260.

Tanzimat I, Maarif Matbaası 1940

Tanzimat ve Edebiyat-Osmanl İstanbul'unda Modern Edebi Kültür, (haz.) Mehmet Fatih Uslu, Fatih Altuğ, (İstanbul: Türkiye İş Bankası Yayınları, 2014).

Tanzৃmat, Halil İnalcık-Mehmet Seyitdanlıŏlu, 2. Bask1, (İstanbul: Türkiye İş Bankası Kültür Yayınları, 2011),

Tanzimat'tan Cumburiyet'e Türkiye Ansiklopedisi, c.I, (İstanbul İletişim Yayınları, 1990), s.99-102; 
Toprak, Zafer, "Fikir Dergiciliğinin Yüzyllı", Türkizye'de Dergiler Ansiklopediler, (İstanbul: Gelişim Yayınları, 1984).

Türk. Edebiyatı Taribine Bir Bakış, Editör: M. Kayahan Özgül, (Ankara: Kurgan Yayınları, 2015).

Türköne, Mümtaz’er. Milletler ve Milliyetçilikler, Etkileşim Yayınları, İstanbul 2012.

Tütengil, Cavit Orhan. İngiltere'de Türk Gazeteciliği, İstanbul: Belge Yayınlar1 1985.

Uslu, Mehmet Fatih. Çatışma ve Mürakere-Osmanli'da Türkęe ve Ermenice Dramatik Edebiyat, İstanbul: İletişim Yayınları, 2014.

Ülken, Hilmi Ziya. İslam Medeniyetinde Tercümeler ve Tesirler, İstanbul: Şirketi Mürettebiye Matbaas1, 1948.

Ülken, Hilmi Ziya. Türkiyye'de Çăgdaș Düşünce Taribi, c. 1, Konya: Selçuk Yayınları,1966.

Ülken, Hilmi Ziya. Uyanış Devirlerinde Tercümenin Rolü, İstanbul: Türkiye İş Bankası Kültür Yayınları, 2016.

Ziyad Ebuzziya. Şinasi, Hazırlayan: Hüseyin Çelik, İstanbul: İletişim Yayınları, 1997. 